\title{
Antimicrobial surfaces: a review of synthetic approaches, applicability and outlook
}

\author{
Urbashi Mahanta $^{1}$, Mudrika Khandelwal ${ }^{1}$, and Atul Suresh Deshpande ${ }^{1, *}$ (D) \\ ${ }^{1}$ Department of Materials Science and Metallurgical Engineering, Indian Institute of Technology Hyderabad, Kandi, \\ Sangareddy 502285, Telangana, India
}

Received: 14 May 2021

Accepted: 29 July 2021

Published online:

10 August 2021

(C) The Author(s), under exclusive licence to Springer Science+Business Media, LLC, part of Springer Nature 2021

\begin{abstract}
The rapid spread of microorganisms such as bacteria, fungi, and viruses can be extremely detrimental and can lead to seasonal epidemics or even pandemic situations. In addition, these microorganisms may bring about fouling of food and essential materials resulting in substantial economic losses. Typically, the microorganisms get transmitted by their attachment and growth on various household and high contact surfaces such as doors, switches, currency. To prevent the rapid spread of microorganisms, it is essential to understand the interaction between various microbes and surfaces which result in their attachment and growth. Such understanding is crucial in the development of antimicrobial surfaces. Here, we have reviewed different approaches to make antimicrobial surfaces and correlated surface properties with antimicrobial activities. This review concentrates on physical and chemical modification of the surfaces to modulate wettability, surface topography, and surface charge to inhibit microbial adhesion, growth, and proliferation. Based on these aspects, antimicrobial surfaces are classified into patterned surfaces, functionalized surfaces, superwettable surfaces, and smart surfaces. We have critically discussed the important findings from systems of developing antimicrobial surfaces along with the limitations of the current research and the gap that needs to be bridged before these approaches are put into practice.
\end{abstract}

\section{Introduction}

The human body hosts a large variety of bacteria, fungus, and viruses, on and within the tissues and biofluids, and various sites including the gastrointestinal tract and oral mucosa. However, an invasion and/or change in the population of the microbes leads to infections that are detrimental to an individual's health [1,2]. While infections are common, we have seen in the past and also present (COVID-19 caused due to the novel coronavirus

Handling Editor: Annela M. Seddon.

Address correspondence to E-mail: atuldeshpande@msme.iith.ac.in 
SARS-CoV-2 virus) that infections have led to pandemics, with a huge loss to health, economy, and lives.

The transmittance/spread of infection can occur via air, water, and contact with infected individuals, depending on the microbe. The typical approaches used to manage infections involve preventive measures such as avoiding contact, use of chemical disinfectant, UV light sterilization, personal sanitization, and protective equipment [3]. Many infections have been eradicated or kept under control through immunization by vaccines. However, the development of vaccines and remedies for new pathogens takes time and thus prevention of transmittance of infections is the key to its management. Particularly, in the case of COVID-19, a huge emphasis is rightly on disinfecting surfaces where the pathogen may be present. It has been observed that the SARS-CoV-2 virus remains active on various surfaces like metals, plastics, fabrics, or surgical masks for durations up to 7 days $[4,5]$.

Chemical sanitization is one of the efficacious ways to arrest the proliferation of microorganisms. However, repeated sanitization, particularly of large and open areas is practically and economically challenging. Moreover, extended interaction with such chemicals for sanitization purposes (chlorine, hydrogen peroxide, sodium hypochlorite, ethanol) may lead to the enhanced probability of contracting long-term heart and lung diseases [3]. Studies show that continual use of alcohol can lead to alcohol poisoning in children which can cause drowsiness, vomiting and in serious cases can cause respiratory arrest. In addition, the dermal contact of ethanol can be responsible for skin irritation and long-term exposure can result in dryness of skin with itching [6]. Another popular disinfection method is UV treatment, which can cause skin burns and skin cancer [3].

Given all these concerns, there is an increasing impetus on designing and developing antimicrobial surfaces which provide a benign and sustainable approach to prevent the spread of infections. The antimicrobial surfaces should be effective to prevent fouling by a broad spectrum of pathogens in one of the two ways. The first approach involves killing the microorganisms (cidal activity) to prevent their transmission, while the second approach is to prevent the attachment, survival, and growth of microorganisms and biofilm formation (static activity). These types of surfaces are of huge interest in various fields such as healthcare, public transportation systems, household hygiene, food protections, sportswear, some of which are also discussed in this paper [7-10].

There are a few recent reviews on antimicrobial surfaces which focus on approaches for developing both microbicidal and microbiostatic surfaces. Ding et al. have reviewed an antibacterial surface with strategies covering both monofunctional and multifunctional antibacterial surfaces [11]. Similarly, Zou et al. have summarized antibacterial surfaces with dual functionality. They have discussed the surfaces which show simultaneously antiadhesive and bactericidal activities and those with switchable antiadhesive and bactericidal activities [12]. Wei et al. have also focused on versatile antibacterial coating which covered self-defensive coatings, synergistic antibacterial coating, and smart kill and release antibacterial coating [13]. However, all the previous literature limited their review only to bacteria. Also, some of the reviews only focused on one type of strategies such as based on their topography [7] or wettability [14].

The present review furnishes a comprehensive survey of various approaches to develop antimicrobial surfaces against bacteria, fungi, and viruses by modulating physical and chemical properties, particularly by altering wettability (superhydrophobic and superhydrophilic), surface chemistry (functionalization), and topography. It must be understood that all the microbes are different in structure and pathological behavior. Thus, they have different mechanisms of attaching to a surface and transmitting to a body and causing infections, making it difficult to fabricate a universal antifouling surface. Therefore, it becomes important to understand the cause of antifouling activity and its specificity. This review first summarizes the structure of bacteria, fungus, and viruses to facilitate a better understanding of interaction with surfaces. Further, the reports on antimicrobial surfaces are classified based on surfaces developed by physical modification (patterned surfaces), chemical modification (functionalized surfaces), a combination of physical and chemical modifications (superhydrophobic, superhydrophilic surfaces), and smart surfaces. Finally, the application-related challenges, unanswered fundamental questions, and future prospects of antimicrobial surfaces are discussed. 


\section{The infectious microbes}

Particular microorganisms such as viruses, bacteria, and fungi may cause harm to human health and hygiene and have been known to be the causative factors for various infectious diseases. As mentioned before, they are all very different in structure and pathological behavior. Thus, before discussing the various approaches to create antimicrobial surfaces, it is useful to understand their structure and interaction with surfaces.

\section{Bacteria}

Bacteria is a family of single-cell microorganisms that may vary in size and mass and are 10-100 times bigger than viruses. Typically, bacteria are $1-3 \mu \mathrm{m}$ in length and are shaped like a sphere or a rod. Grampositive bacteria comprise a cytoplasmic membrane surrounded by a dense coating of peptidoglycan, whereas, gram-negative bacteria comprise a cytoplasm surrounded by three layers made up of an inner surface/membrane, a layer of peptidoglycan, and an outer membrane as shown in Fig. 1a. The outer surface is uneven and undulating with an internal leaflet holding phospholipids and an external leaflet formed by lipopolysaccharide $[15,16]$.

The attachment of bacterial cells to a surface occurs in two phases. The early phase of attachment is rapid but reversible and consists of hydrodynamic and electrostatic interactions. The majority of the bacterial surfaces are negatively charged, and at the beginning of the biofilm formation process, they get seamlessly linked with external surfaces having a positive charge. The next stage of this process cannot be reversed and is a long-drawn process that may continue for many hours. The interaction of the hydrophobic part of the external cell membrane to other surfaces is through van der Waals interaction. Furthermore, particular proteins are involved in the process of converting reversible cell attachment into an irreversible one. In addition, various classes of extracellular organelles such as flagella, pili, and curli fibers help in attachment to the surface using specific adhesins (proteins). Type I pili attach particularly to glycoproteins containing Alpha-D-mannose, whereas, type IV pili attach to phosphatidylethanolamine [17].

Commonly, the deposition of bacterial matter leads to the development of biofilms. The discharged extracellular polymeric substances (EPS) from cells in biofilm deposit on various surfaces protects them from wear and tear or any physical damage caused by the movement of fluids. In addition, the development of intransigence to antibiotics/antimicrobial agents by the microbes is known to be facilitated by the biofilm [17].

\section{Fungi}

Fungi are multicellular eukaryotes with cells having a true nucleus and a complex internal structure as shown in Fig. $1 \mathrm{~b}$ and are normally found as environment-resistant spores and molds. Glucans, chitin, and glycoproteins are the important building block in the cell wall of the fungus. The most essential building block in the construction of a cell wall is chitin as it is located adjacent to the plasma membrane. Species of fungi, morphotype, and growth stage of the fungi determine the configuration and the structure of the outer cover [18]. Fungi are competent to invade complex substrates very efficiently by forming tubular, thread-like cells called hyphae. These cells can penetrate the substrates upon which they nourish [19]. The development of a biofilm in fungi consists of the sequential process where, in the initial stage, the attachment of fungi to a surface subsequently becomes an accretional process. It implies that cell-to-cell adhesion results in the metamorphosis of the biofilm into structurally layered and distinguishable biomasses. In the last stage of the process, also referred to as the maturation step, there is a decrease in the yeast-like growth and there is an increase in hyphal growth. Also, an extracellular matrix covers the biofilm. Several adherence factors and transcription factors determined the development of the biofilm. The attachment step in the pathogenic yeast C. albicans, biofilm is achieved through the cell appendages like adhesive proteins in the outer layer of the cell which are generally considered in the class Glycosyl Phosphatidyl Inositol (GPI)-anchored proteins. These cell wall proteins serve as membrane anchors for many cell surface proteins.

The extracellular matrix (ECM) components are capable of performing multiple functions, for example attaching to various surfaces, cell-to-cell binding, and storehouse for cell nutrients. Additionally, an extracellular matrix may serve as a protective layer for the biofilm cells from any antimicrobial 
(a)

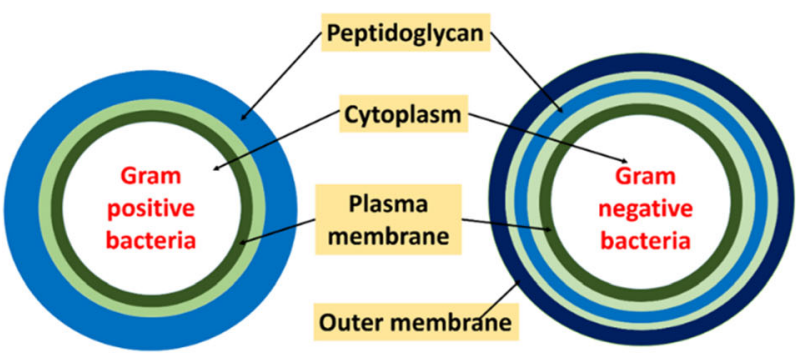

(c) (b)
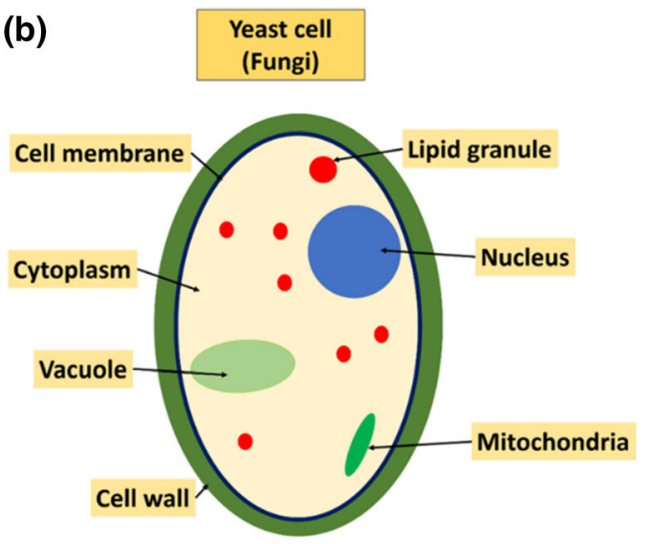

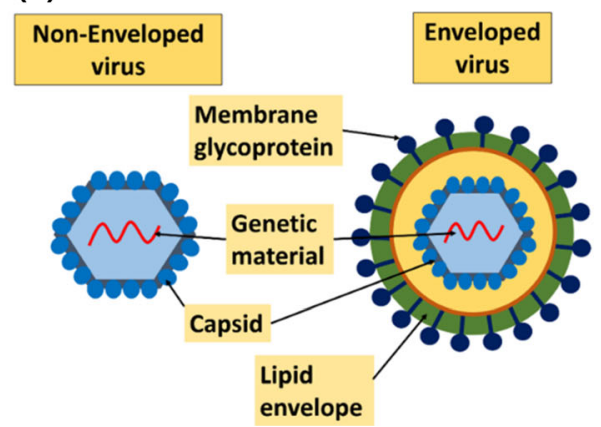

Figure 1 Schematic diagram of various types of microorganisms a Bacteria b Fungus $\mathbf{c}$ Virus.

substances or the influence of the defensive mechanism present in the host tissue. In such cases, it may serve as a protection from phagocytic cells and also support and strengthen the cohesion of the biofilm to obviate infiltration of toxins into the biofilm [20].

Chemical analysis of the ECM of C. albicans has led to the detection of glucose, hexosamine, protein, extracellular DNA (eDNA), and a few other components. Such an analysis was complemented through functional assays for biofilm integrity and adherence after enzymatic hydrolysis of ECM components. Overall biofilm integrity was found to depend upon multiple ECM components like $\beta-1,3$ glucan, chitin, protein, and eDNA. Additionally, $\beta-1,3$ glucan displays the greatest propensity to contribute to the substrate for cell-cell adherence [21].

\section{Virus}

Viruses are holoparasites that need a suitable living host for their survival and growth. They are the tiniest agents of infectious diseases, mostly round in shape and with their size ranging from about 20 to $200 \mathrm{~nm}$ in diameter. A virus comprises of DNA or RNA inside a protective protein coat known as a capsid [22]. The shape of the capsid differs for different viruses. The interaction of viral proteins to the host cell membranes is crucial for the entry of the virus into the host cell followed by replication of the viral genome and finally production of progeny particles. A virus has to cross the plasma membrane of the host cell to replicate its genome. A few types of viruses are surrounded by an outer membrane of the lipid bilayer and are known as enveloped viruses. These viruses develop their envelope from the outer layer of the plasma or the inner layer between the host cell [23]. A schematic of the enveloped and nonenveloped virus is shown in Fig. 1c.

The ability to develop a biofilm has been detected among bacteria, fungi, and yeast since the initial observation recorded in 1978. This phenomenon is an important field of research even today. However, the concept of biofilm formation in viruses is still under research. Some viruses show biofilm-like assemblies, for example in the case of Human T-cell leukemia virus type 1 (HTLV-1). It is a retrovirus and its extracellular viral assemblies show apparent commonalities in their organization, composition, and dissemination with bacterial biofilms. Bacterial biofilms, as well as viral assemblies, are composite bonded blocks containing microbial colonies amalgamated with a profuse amount of carbohydrate and 
multimolecular network. Such a composite structure and layout of the viral network give rise to its resistance, strength, and its propensity to proliferate, which corresponds to the particular traits which are common among bacterial biofilms.

In the case of bacterial biofilms, the matrix is constructed by bacteria on their own; on the other hand, in the case of viruses the viral assemblies are formed by the host cell which has been infested by the virus. This is so because of the parasitic properties of the virus which utilizes the cellular mechanism to combine the proteins present in the cells with the viral constituents to form the structure of the viral assembly as the viruses on their own do not possess the capability and the requisite functional metabolism to construct such a structure. In the case of HTLV-1, the viral infestation of the cells triggers the creation of the network of viral assembly which is governed, controlled, and synthesis of ECM and linker proteins present in the cell [24].

A major factor for viral transmission is its capability to survive in a given environment and on a surface. Depending on the type of virus, it remains viable for varying intervals of time which can range from hours to days on surfaces as a fomite. For example, the Hepatitis A virus can remain infectious on a finger pad even after $4 \mathrm{~h}$, although over $60 \%$ of the viruses lose their infectivity in the first hour. Similarly, the respiratory syncytial virus remains viable on rubber gloves for a period of $90 \mathrm{~min}$, clothing gown and paper towel for 30-45 min, and skin for $20 \mathrm{~min}$. Influenza virus and rhinovirus are also known to survive on the skin for a long time [25-28]. According to recent studies, coronavirus can remain viable on a surface for a significantly longer period compared to other viruses. For example, the coronavirus remains active on wood for 4 days, metal for 5 days, cardboard for $24 \mathrm{~h}$, and plastic for 2-3 days [4].

\section{Microbial cell-surface interaction}

The viability and proliferation of all microorganisms on various surfaces depend largely on the physical and chemical linkage among the outer membrane of these microorganisms and the surfaces. Microbes drift toward a solid surface leading to adsorption and colonization on the surface. This surface accumulation followed by the proliferation of microbes is known as biofilm formation [29]. During this course of time, microorganisms experience diverse biological changes and form an extracellular matrix. The constituents of ECM differ with microbe and species and also depend on the growth conditions. In bacteria, ECM mainly consists of polysaccharides, proteins, and extracellular DNA. They serve various functions for example shielding free-living bacteria and assist genetic exchange. Also, ECM is the basis of a biofilm, which encourages cell to cell and cell to surface interaction at inanimate surfaces as discussed above $[7,29,30]$. In the case of fungi, the ECM also provides antifungal resistance by binding to antifungal agents and preventing entry to their deliberate targets at the surface or within fungal cells, other than acting as a protective barrier against chemical and biological agents [31]. In the case of viruses, ECM is used for adhesion to the target cells followed by interaction with cell surface receptors permitting their entry [32].

Since microbial cell attachment to the surface is the crucial step of biofilm formation, knowledge of cellsurface interaction is very important to control biofilm development. Surface charge and wettability are the two most important factors that influence microbial cell-surface interaction [33, 34]. In general, bacteria are negatively charged. The cell wall in grampositive bacteria consists of peptidoglycan which is embedded with teichoic acids. Teichoic acids are anionic cell surface polymers that contribute to bacterial cell charge, whereas, in the case of gram-negative bacteria, the outer membrane consists of phospholipids and lipopolysaccharides which confer net negative charge to the cell surface [35]. The distribution of charge in virus particles is due to a distinct arrangement of protein within its structure, which is different for different types of viruses $[36,37]$. On the other hand, the charge on fungi is because of the existence of mannoproteins found on the fungal cell wall. These mannoproteins are linked to beta-glucans via glycophosphate groups which give a negative charge to the fungal cell wall [38]. The negative cells interact strongly with the positively charged surface via electrostatic interaction.

Similarly, surface hydrophobicity is one of the major factors responsible for attachment and detachment from the surface which can enhance biofilm formation. In bacteria, fimbriae contain a high content of hydrophobic amino acid residue and are responsible for cell surface hydrophobicity and 
attachment [39]. Also, various proteins are closely related to cell surface hydrophobicity that affects the attachment of fungus such as C. albicans to the surface. According to the studies, mycolic acid-containing organisms are more hydrophobic, and an increase in the chain length of mycolic acid increases cell hydrophobicity [40].

Given these considerations, the approaches to create antimicrobial surfaces involve tuning the surface morphology and chemistry. In the next few sections, literature on creating antimicrobial surfaces based on superhydrophobicity, superhydrophilicity, pattern, and functionalization is discussed.

\section{Antimicrobial approaches}

The chemical and physical interaction of a surface with a microbe is modulated to impart an antimicrobial nature to a surface. This involves tuning the surface through physical or chemical methods. To facilitate readability, the literature review on developing antimicrobial surfaces has been classified into four sections.

1. Patterned surfaces

2. Functionalized surfaces

3. Superwettable surfaces

a. Superhydrophobic surfaces

b. Superhydrophilic surfaces

\section{Smart surfaces}

The above classification is based on the type of modifications/approaches used to develop an antimicrobial surface. The first strategy, i.e., patterned surface is a physical modification of surface in which microbes are either unable to come in contact with the surface due to steric hindrance or killed due to physical disruption of cells owing to penetration of the surface features. The second class is that of the functionalized surfaces where a purely chemical modification is done to either inhibit microbe-surface interaction or killing the microbes on interaction. The next approach is to produce superwetting surfaces which require a combination of both physical and chemical modification. It is known that for developing superhydrophobic and superhydrophilic surfaces both roughness (created by physical modification) and chemical modifications are required. However, these surfaces can only inhibit microbial adhesion and are thus treated as a separate category. It must be pointed out here that the above-discussed classes are maybe effective either in killing or inhibiting microbial adhesion. Recently, various surfaces with multiple modes of action have been sought such as surfaces with switchable properties which can both kill and inhibit the microbes simultaneously. These types of surfaces can be developed by incorporating biocidal agents and stimuli-responsive polymers as antifouling material. These approaches have been summarized as the fourth category of smart surfaces, the schematic of all the strategies is illustrated in Fig. 2.

\section{Patterned surfaces}

Nature is full of examples including lotus leaf, taro leaf, and shark skin that prevent microbial attachment as a result of micro and nanostructured surfaces. Some surfaces for instance gecko skin, cicada wings, and dragonfly wings can even exhibit microbicidal activity [41]. Details of the structure and activity of some of the natural biocidal surfaces are shown in Table 1.

The biocidal efficiency of a patterned antimicrobial surface is dependent on the surface topography and the microbe species. Hasan et al. have studied the antibacterial action of the cicada wing surface on both gram-positive and gram-negative bacteria of rodshaped and coccoid shape. The surface topography of cicada wings consists of hexagonally packed uniform nanopillars of height $200 \mathrm{~nm}$, base and cap diameter of $100 \mathrm{~nm}$ and $60 \mathrm{~nm}$, respectively, and spacing of $170 \mathrm{~nm}$ for Psaltoda claripennis species (of cicada). It was found that only gram-negative bacteria, regardless of their shape, are significantly distorted and eventually killed by the wings of cicada [46]. This is because the cell walls of both gram-positive and gram-negative bacteria are different. The cell wall of gram-positive bacteria comprises several layers of peptidoglycan which makes it more rigid compared to that of gram-negative bacteria that have a single layer of peptidoglycan and a second layer consisting of phospholipids.

Likewise, Yang et al. have reported antibacterial surfaces by developing a honeycomb pattern on a silicon wafer with varied pore sizes from 0.5 to $10 \mu \mathrm{m}$ using photolithography and deep reactive ion etching. It was observed that the pattern of $1 \mu \mathrm{m}$ significantly decreases the bacterial adhesion and growth 
Figure 2 Schematic diagram of different antimicrobial surfaces.

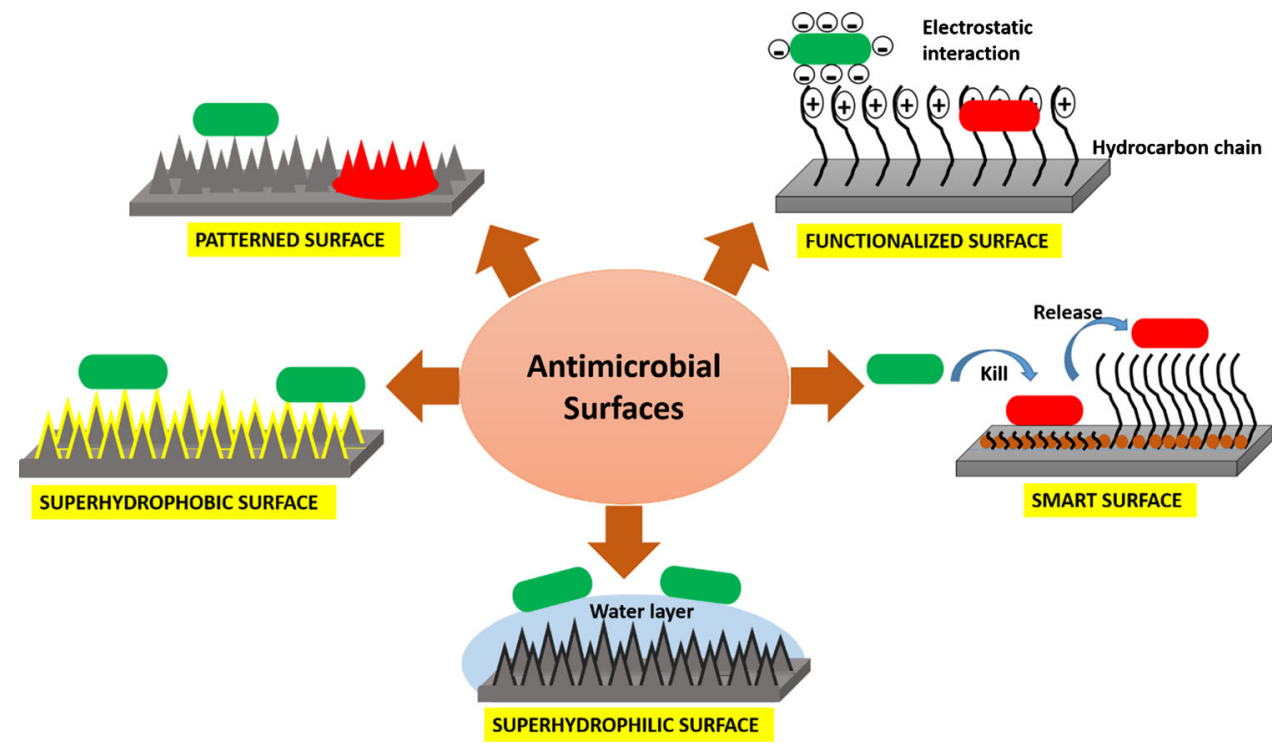

Table 1 Summary of natural biocidal surfaces

\begin{tabular}{llll}
\hline $\begin{array}{l}\text { Natural surface } \\
\text { Surface topography (height, } \\
\text { spacing) }\end{array}$ & $\begin{array}{l}\text { Contact } \\
\text { angle }\end{array}$ & $\begin{array}{l}\text { Effective against (type of } \\
\text { microbes) }\end{array}$ \\
\hline $\begin{array}{l}\text { Claripennis) } \\
\text { Dragon fly }\end{array}$ & $200 \mathrm{~nm}, 170 \mathrm{~nm}$ & $158^{\circ}$ & Gram-negative bacteria \\
& $240 \mathrm{~nm},>200 \mathrm{~nm}$ & $153^{\circ}$ & $\begin{array}{l}\text { Gram-negative bacteria } \\
\text { Gram-positive bacteria } \\
\text { Spore (Fungus) }\end{array}$ \\
Gecko skin & $3000 \mathrm{~nm}, 500 \mathrm{~nm}$ & $150^{\circ}$ & $\begin{array}{l}\text { Gram-negative bacteria } \\
\text { Gram-positive bacteria }\end{array}$ \\
\hline
\end{tabular}

and biofilm formation of S. aureus and E. coli. The reason behind the enhanced antibacterial behavior of $1 \mu \mathrm{m}$ pattern size is due to the two key aspects. First is the accessibility of favorable attachment sites. The attachment sites must facilitate a greater contact area between cell and substrate with minimal cell damage. For $1 \mu \mathrm{m}$ pattern, preferable adhesion sites are much lesser as compared to that of larger pattern size, as $1 \mu \mathrm{m}$ pattern causes large cell deformation by trapping the cells inside the pores. This was observed for E. coli cells which have a similar dimension as that of the pattern. The second aspect is the physical confinement which hinders the growth and proliferation of bacteria [47]. A similar result was seen for micronsized patterns of comparable dimensions [48]. Xiang et al. have reported the effect of micro-nanopillar array on bacterial inhibition. Titania $\left(\mathrm{TiO}_{2}\right)$ micronanopillar with motif size of $0.6 \mu \mathrm{m}$ reduced bacterial adhesion by $62 \%$ for S. aureus (cell size is $1 \mu \mathrm{m}$ ) and
$73 \%$ for E. coli (cell size is $1-2 \mu \mathrm{m}$ long and $0.5 \mu \mathrm{m}$ wide) after $30 \mathrm{~min}$ as compared to that of flat surface [49]. Similarly, Ivanova et al. have reported the bactericidal activity of patterned black silicon. According to their findings, $500 \mathrm{~nm}$ height nanoprotrusions showed similar killing efficiency to that of dragonfly wings for $\mathrm{S}$. aureus and $\mathrm{B}$. subtilis with a killing rate of $4.5 \times 10^{5}$ cells killed $\mathrm{cm}^{-2} \mathrm{~min}^{-1}$ and $1.4 \times 10^{5}$ cells killed $\mathrm{cm}^{-2} \mathrm{~min}^{-1}$, respectively. However, black silicon showed higher killing efficiency than dragonfly wings for P. aeruginosa [50].

Rosenzweig et al. have developed a poly (methyl methacrylate) nanopillar structure and studied their fungicidal properties. The nanostructured surface pillars were fabricated with a periodicity of 170,320 , and $500 \mathrm{~nm}$. It was observed that nanopillar structure showed antifungal activity in the increasing order of periodicity $170 \mathrm{~nm}<320 \mathrm{~nm}<500 \mathrm{~nm}$ as shown in Fig. 3 (a) and (b). Compared to the flat surface, spores 


\section{A. fumigatus}
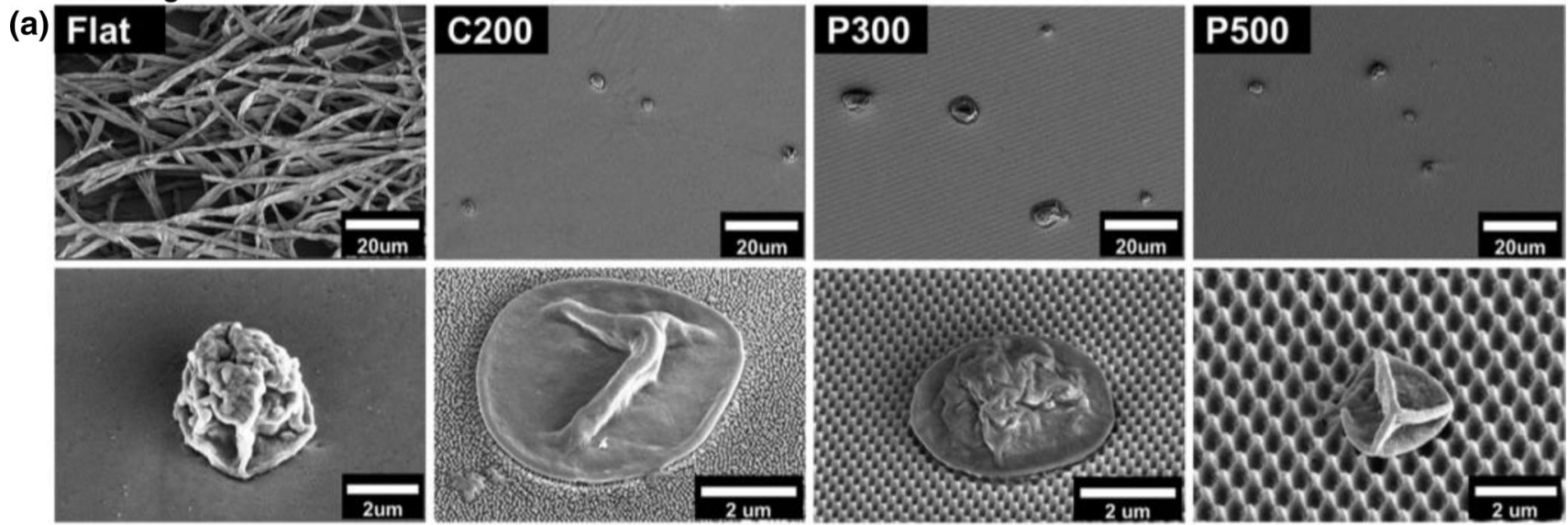

\section{F. oxysporum}
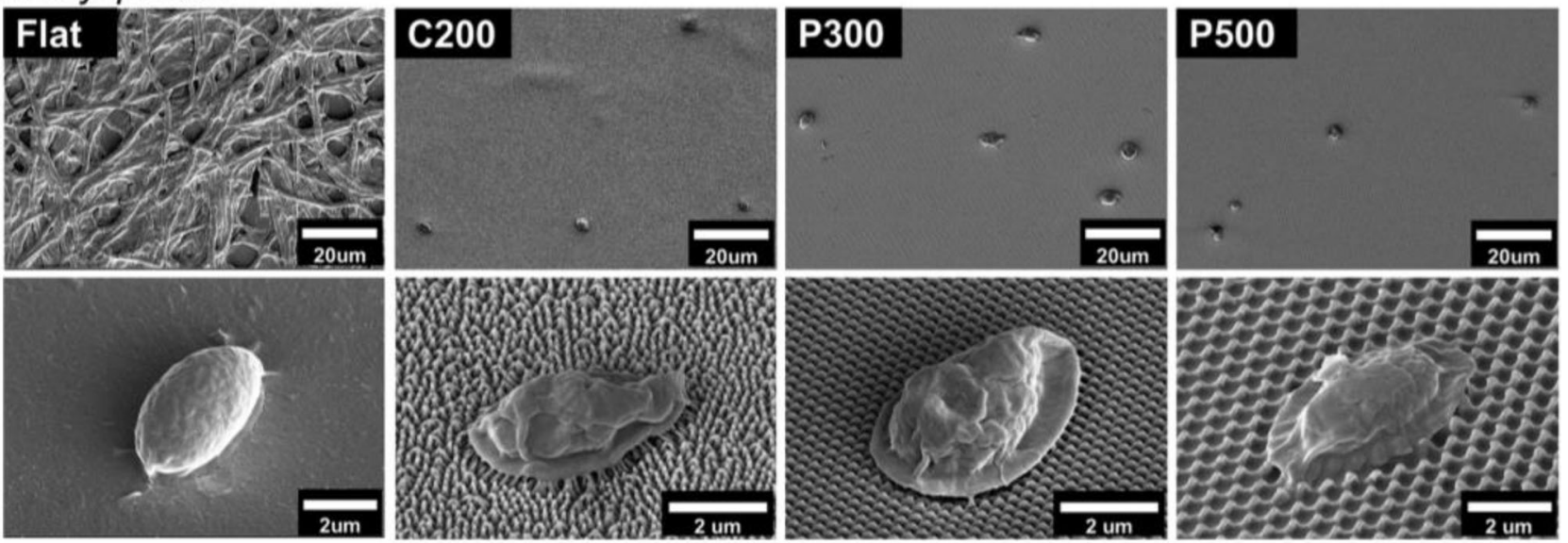

(b)
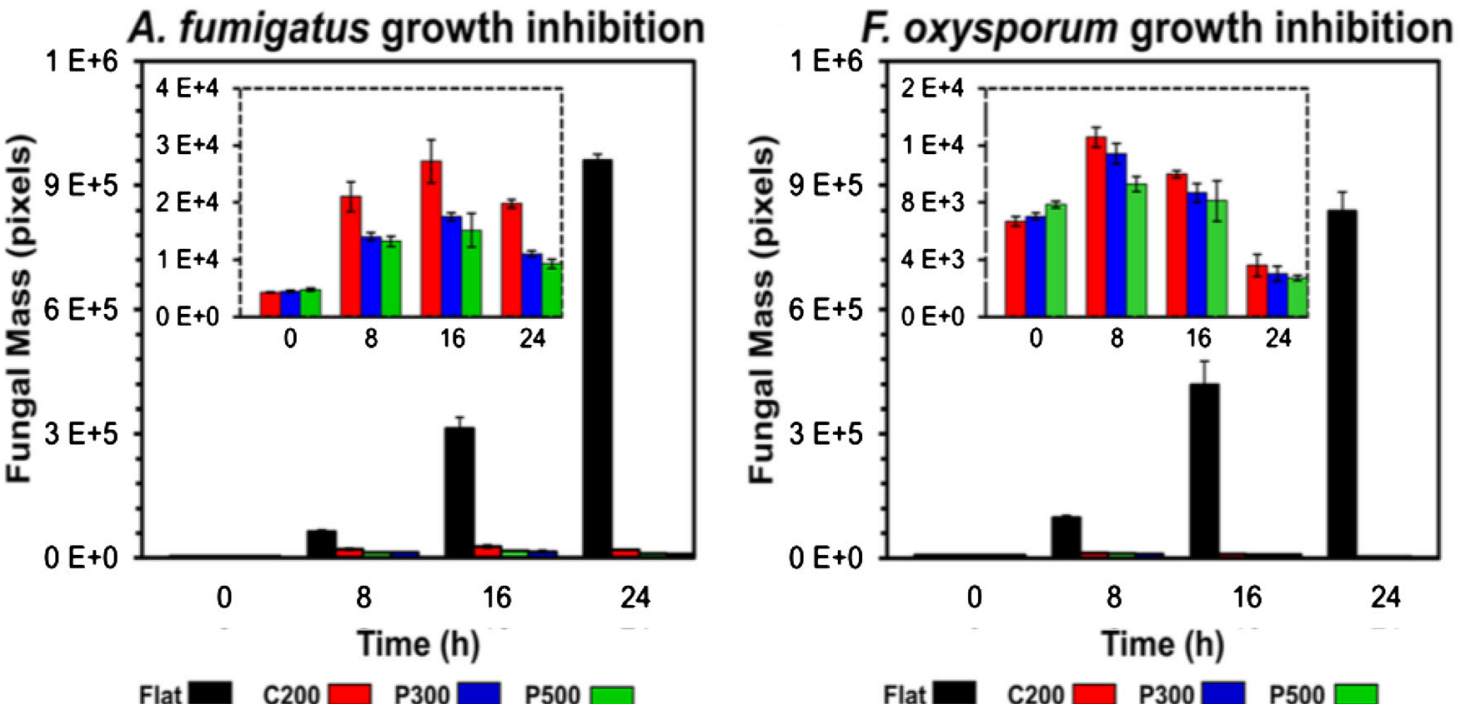

Figure 3 a SEM image of A. fumigatus and F. oxysporum on flat and nanopillared surfaces $\mathbf{b}$ Antifungal activity of A. fumigatus and F. oxysporum at different time intervals. Adapted with permission from Ref. [51] Copyright (2019)American Chemical Society. 
started deforming on the nanopillared surface and the development of the germ tube is disrupted and detachment of spores starts after $16 \mathrm{~h}$ and $8 \mathrm{~h}$ for $\mathrm{A}$. fumigatus and F. oxysporum, respectively. This result may appear contradictory to the observations for antibacterial activity discussed above as the sizes of the cell and mechanosensing mechanism are different [51, 52]. However, the fundamental understanding behind the mechanism of antimicrobial activity of patterned surfaces is very rudimentary at this stage and needs further work.

Furthermore, Hasan et al. have reported antibacterial and antiviral Al 6063 alloy nanostructured surface prepared by wet chemical etching. The nanostructures of width $23 \mathrm{~nm} \pm 2 \mathrm{~nm}$ were orientated randomly into parallel ridges with a root-meansquared roughness of $995 \pm 114.7 \mathrm{~nm}$. To check the effect of surface structure on antibacterial properties, S. aureus (gram-positive) and P. aeruginosa (gramnegative) bacteria were tested. Both types of bacterial cells were deformed on the nanostructured surface and more than $87 \%$ of attached cells were rendered nonviable. The reason for bactericidal activity was attributed to the rupturing of the bacterial cells. The effect of nanostructured surfaces on viruses was studied using Respiratory syncytial virus (RSV) and Rhinovirus (RV). Within two hours of exposure, the etched Al surface showed remarkably lower viable viruses compared to that of flat $\mathrm{Al}$ surface and all viruses were killed after $24 \mathrm{~h}$. However, the RV virus was more susceptible to the nanostructured surface as compared to that of the RSV virus. Also, the same surface was tested against SARS-CoV-2, and virus viability was examined for different intervals of time up to $48 \mathrm{~h}$. The viability of viruses was reduced after three hours of exposure, and no live viruses were observed after six hours of exposure. In comparison, on the control surface, significant depletion of live viruses was noticed only after $24 \mathrm{~h}$ of exposure. A period of $48 \mathrm{~h}$ is needed for the elimination of all the viable viruses from the control surface. The reason for virucidal activity is not clear, and the authors have attributed it to nanoscale roughness which can rupture the virus envelope. Also, the size of the viruses is very small and thus can get trapped in the structure which may be detrimental to their viability $[53,54]$.

From the above literature of biocidal activity on patterned surfaces, we can conclude that the biocidal mechanism on the patterned surface is due to the cell rupturing upon penetration of surface followed by the death of microbes as shown in Fig. 4. However, this mode of action may not be equally effective against the microbes having thicker cell walls or additional envelopes. Another important reason for the antimicrobial activity is the trapping of cells in the structure leading to cell death as shown in Fig. 5. The summary of the literature on patterned antimicrobial surfaces is included in Table 2.

\section{Functionalized surfaces}

Functionalized surfaces can be developed by modifying a surface with a material that can actively kill or inhibit the microbes. The mode of action for functionalized surfaces can be through contact killing of the microbe by functionalized surface due to the materials chemical groups [59], or the functionalized surface generates heat, reactive species on exposure to external stimuli to disrupt the activity of microbes [60].

The chemically active functionalized surfaces involve the use of non-leachable materials such as polycations, which provide effective biocidal activity through direct contact with microbes. Such a surface with polycation functionalization enhances the adsorption of negative surface charged microbes by electrostatic interaction between the cell membrane and material surfaces [61]. As a consequence, the genetic material of the microbes undergoes leakage and loss its effectivity. This is one of the most promising approaches for a wide range of microbes.

Lin et al. have reported the role of polyethyleneimine and its molecular weight on bactericidal (S. epidermidis, S. aureus, P. aeruginosa, and E. coli) and fungicidal (S. cerevisiae, C. albicans) activity. They observed that higher molecular weight polymer showed higher microbicidal activity. This is because the polymer chain length higher than or equal to the size of bacteria facilitates easy penetration into the bacterial cell and destroys the cell membrane [62].

Wong et al. have reported layer-by-layer film of $\mathrm{N}, \mathrm{N}$-dodecyl,methyl-polyethylenimine with a polyanion, such as poly(acrylic acid) to develop an effective microbicidal surface against $S$. aureus, E. coli, and influenza (H1N1) virus. Both high positive charge density and length of alkyl chains are important parameters. Also, a higher number of bilayer deposition was necessary for higher virucidal activity as compared to that of bacteria, as the size of 


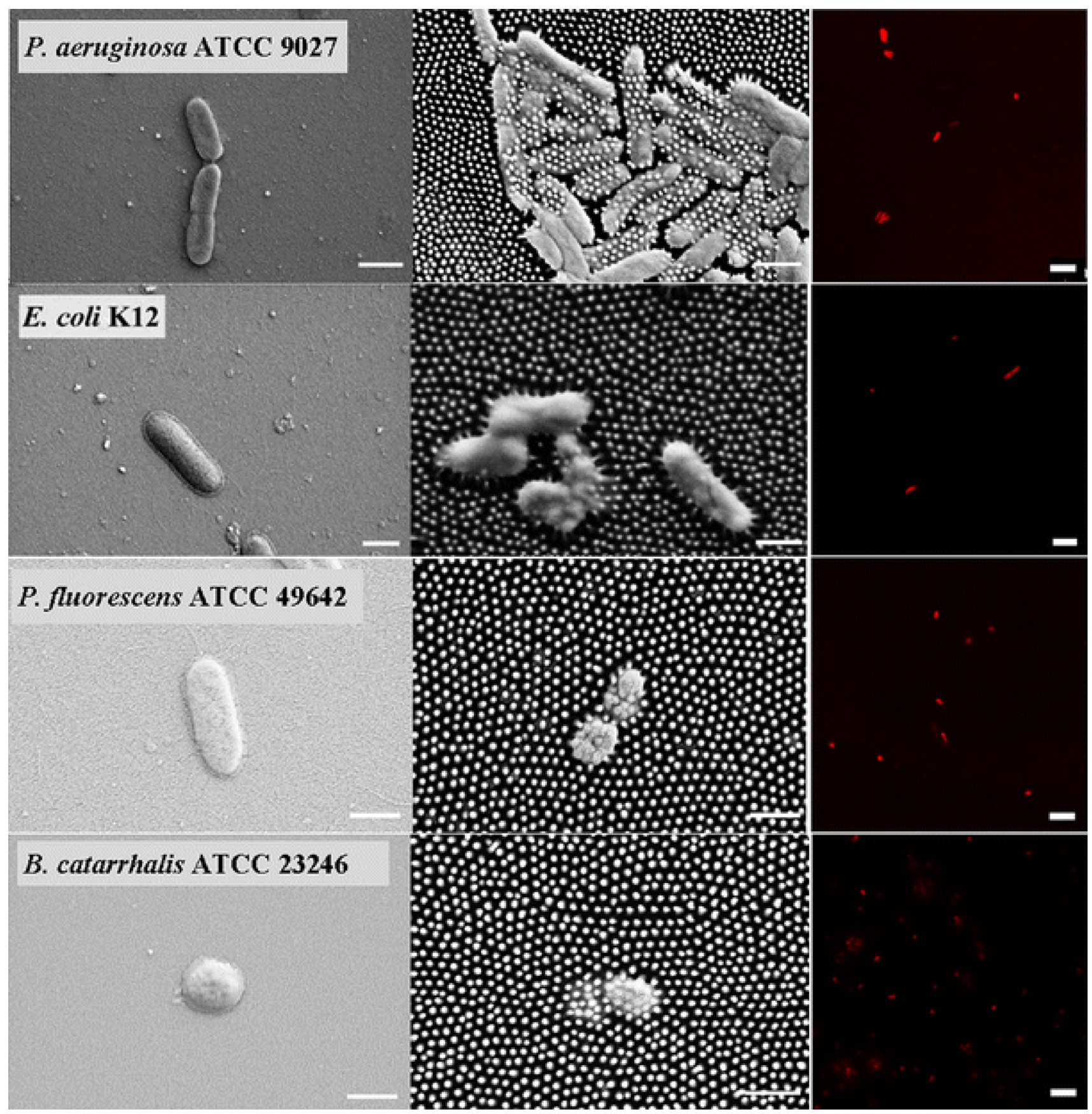

Figure 4 Antibacterial mechanism of cicada wing surface. Adapted with permission from Ref. [46] Copyright (2013) Springer.

a virus $(\sim 100 \mathrm{~nm})$ is approximately $1 / 10$ th size of bacterium $(\sim 1 \mu \mathrm{m})$. The lower antiviral activity observed for a lesser number of bilayers is due to the fact that the voids which are present on the surface are too big to fit a virus. The possible mechanism for antimicrobial activity is through contact killing of microbes by polycationic chains [59].

Silva et al. have developed Silica NPs modified surface using positively charged amine group which resulted in a $50 \%$ reduction of vesicular stomatitis virus G (VSV-G) transduction. This is due to the strong interaction of modified silica particles with the virus, which resulted in the blockage of direct contact among cells and viral particles [63]. Likewise, Meder et al. have developed colloidal alumina particles functionalized with an amine group and different functional groups to investigate their controlled interaction with viruses [64]. 


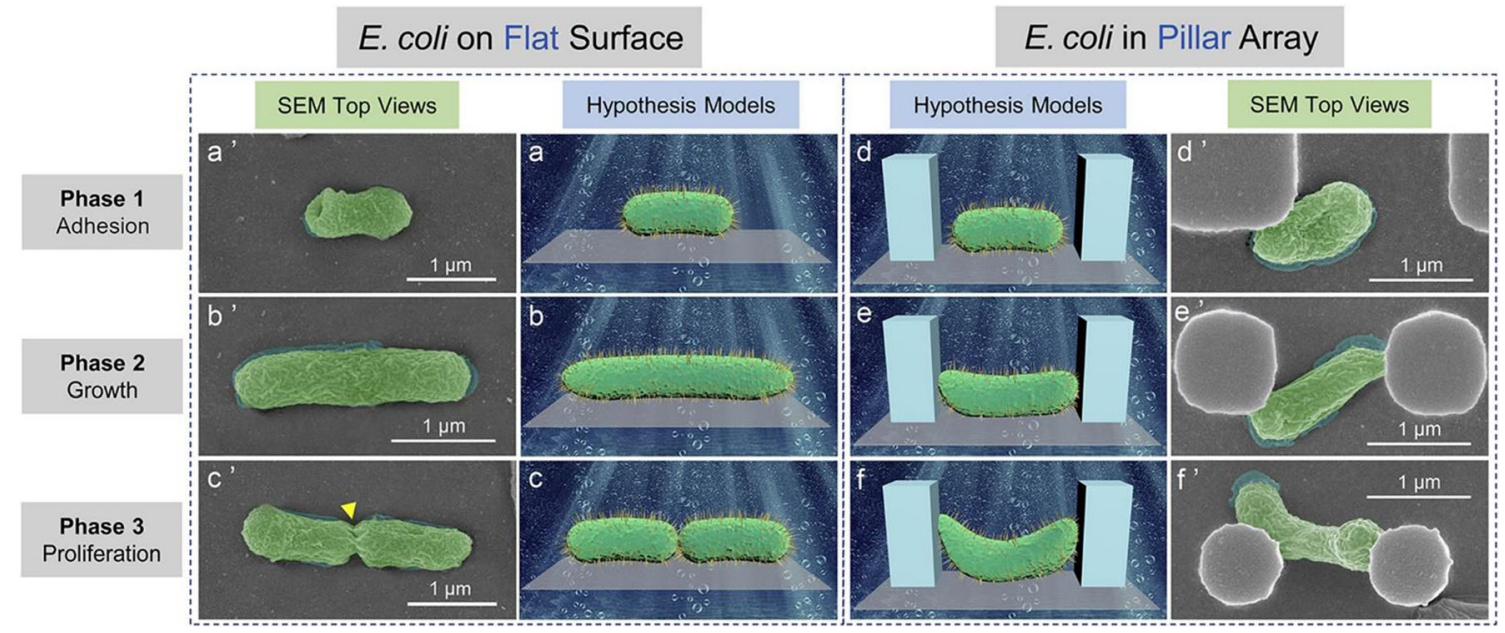

Figure 5 Antibacterial mechanism of patterned micro-nanopillar surface. Adapted with permission from Ref. [49] Copyright (2019) KeAi.

Donskyi et al. have shown the antiviral activity of functionalized nanographene sheets through synergistic electrostatic and hydrophobic interaction. They have developed nanographene derivatives functionalized with polyglycerol sulfate and fatty amine and investigated their attachment with the HSV-1 virus. Polyglycerol sulfate allows electrostatic interaction with the virus, while alkyl chains provide enhanced antiviral action through hydrophobic interactions [65].

It has been observed that some surfaces are effective against only enveloped viruses but not against non-enveloped viruses. Tuladhar et al. have reported the role of hyperbranched quaternary ammonium coating against influenza virus (enveloped) and poliovirus (non-enveloped) virus. Virucidal activity of hyperbranched quaternary ammonium was found to be effective for influenza virus alone and the mode of action is through the disruption or detachment of viral envelope by the long-chain lipophilic tails and the high-density end groups [66].

Thus, functionalized surfaces are active against a vast spectrum of gram-positive and gram-negative bacteria, viruses, and fungi. The factors responsible for biocidal activity are the chain length of the alkyl polycation, molecular weight of the polymer, charge density, and so on. For instance, the highest activity against gram-positive bacteria and yeast was shown by a QAC containing chain length of $12-14$ carbons, whereas chain length with 14-16 carbons shows the highest activity against gram-negative bacteria $[67,68]$.
Other than chemically active functionalization, antimicrobial surfaces can be activated by physical methods. One such example is photothermal therapy. The mode of action is based on the generation of local heat by a photothermal agent upon exposure to light of a suitable wavelength. This results in hyperthermia and leads to microbial death by protein denaturation, rupturing of the cell membrane, cellular fluid evaporation, etc. [69, 70]. Yang et al. reported excellent photothermal activity of Silver functionalized $\mathrm{SnS}_{2}$ surface. Antibacterial activity of $100 \%$ growth inhibition against E. coli and S. aureus was achieved with an $\mathrm{Ag}-\mathrm{SnS}_{2}$ concentration of $0.5 \mathrm{mg} / \mathrm{mL}$ after exposure to near-infrared (NIR) for $5 \mathrm{~min}$. The sample was also tested for in vivo antibacterial activity against S. aureus on mice as shown in Fig. 6 [71]. Similarly, photothermal antifungal and antibacterial activity was reported by Lei et al. Polydopamine nanocoating achieved 84\%, 96\%, and 93\% killing efficiency for E. coli, S. aureus, and C. albicans, respectively, upon exposure to NIR [72]. In addition, $\mathrm{UV}$ is also used to activate metal oxides such as $\mathrm{ZnO}$ and $\mathrm{TiO}_{2}$ that leads to the degradation of microorganisms via photocatalysis. Semiconducting oxide generates high-energy electron-hole pair when exposed to radiation (typically UV-visible light) with energy more than the bandgap. These high electronhole pairs bring about redox reactions at the surface of the oxide particles, resulting in the generation of various reactive oxygen species and free radicals which induce oxidative stress in the microbial cell and lead to their death [73, 74]. Kim et al. have 
Table 2 Summary of results reported antimicrobial behavior of patterned surfaces

\begin{tabular}{|c|c|c|c|c|c|}
\hline Material used & Surface topography & Fabrication technique & $\begin{array}{l}\text { Antifouling(A) or } \\
\text { biocidal(B) }\end{array}$ & Microbes tested & Reference \\
\hline Silicon & $\begin{array}{l}\text { Honeycomb pattern with } \\
\text { micron-size pores }\end{array}$ & $\begin{array}{l}\text { Photolithography and deep } \\
\text { reactive ion etching }\end{array}$ & A, B & $\begin{array}{l}\text { S. aureus (gram-positive) } \\
\text { and E. coli (gram- } \\
\text { negative) bacteria }\end{array}$ & {$[47]$} \\
\hline $\mathrm{TiO}_{2}$ & Micro-nanopillar arrays & $\begin{array}{l}\text { Photolithography and RF } \\
\text { magnetron sputtering }\end{array}$ & $\mathrm{B}$ & $\begin{array}{l}\text { S. aureus (gram-positive) } \\
\text { and E. coli (gram- } \\
\text { negative) bacteria }\end{array}$ & [49] \\
\hline PMMA & $\begin{array}{l}\text { Microstructure replicated } \\
\text { from shark skin }\end{array}$ & Polymer imprinting & A & $\begin{array}{l}\text { S. aureus (gram-positive) } \\
\text { and E. coli (gram- } \\
\text { negative) bacteria }\end{array}$ & {$[55]$} \\
\hline PMMA & Nanopillared surfaces & $\begin{array}{l}\text { Nanoimprint lithography } \\
\text { (NIL) }\end{array}$ & $\mathrm{B}$ & $\begin{array}{l}\text { A. fumigatus and F. } \\
\text { oxysporum (Fungus) }\end{array}$ & {$[51]$} \\
\hline Silicon & Micropillar arrays & $\begin{array}{l}\text { Photolithography and dry } \\
\text { etching }\end{array}$ & A,B & $\begin{array}{l}\text { S. aureus (gram-positive) } \\
\text { and E. coli (gram- } \\
\text { negative) bacteria }\end{array}$ & {$[48]$} \\
\hline Black silicon & Nanopillars & Reactive ion beam etching & B & $\begin{array}{l}\text { S. aureus, B. subtilis } \\
\text { (gram-positive) and P. } \\
\text { aeruginosa (gram- } \\
\text { negative) bacteria }\end{array}$ & {$[56]$} \\
\hline Polycarbonate & Nanopillar surface & $\begin{array}{l}\text { Nanoporous anodic aluminum } \\
\text { oxide (AAO) template- } \\
\text { assisted hot embossing and } \\
\text { wet etching }\end{array}$ & B & $\begin{array}{l}\text { E. coli (gram-negative) } \\
\text { bacteria }\end{array}$ & {$[57]$} \\
\hline $\begin{array}{l}\text { Insect wings } \\
\text { (Cicada \& } \\
\text { dragonfly) }\end{array}$ & $\begin{array}{l}\text { Nanostructured surface } \\
\text { with hemisphere, } \\
\text { spherically capped } \\
\text { cones, and cylinders }\end{array}$ & - & $\mathrm{B}$ & S. cerevisiae (Fungus) & {$[58]$} \\
\hline $\begin{array}{l}\text { Aluminum Al } \\
6063 \text { alloy }\end{array}$ & Nanostructured surface & Wet chemical etching & $\mathrm{B}$ & $\begin{array}{l}\text { S. aureus (gram-positive) } \\
\text { and P. aeruginosa } \\
\text { (gram-negative bacteria) } \\
\text { Respiratory Syncytial } \\
\text { Virus and Rhinovirus } \\
\text { (Virus) }\end{array}$ & {$[53]$} \\
\hline $\begin{array}{l}\text { Aluminum Al } \\
6063 \text { alloy }\end{array}$ & Nanostructured surface & Wet chemical etching & $\mathrm{B}$ & $\begin{array}{l}\text { SARS-CoV-2 } \\
\text { (Virus) }\end{array}$ & {$[54]$} \\
\hline
\end{tabular}

reported photocatalytic viral inactivation against MS2 bacteriophage, influenza virus, and murine norovirus using $\mathrm{TiO}_{2}$ nanoparticles prepared with different calcination temperatures. The sample calcined at $700{ }^{\circ} \mathrm{C}$ showed enhanced virucidal activity due to the presence of a mixed anatase-rutile phase [75].

The summary of various studies reported on antimicrobial activity of the functionalized surfaces is listed in Table 3.

\section{Superwettable surface}

The development of biofilm on an external surface occurs by the attachment of microbes to the surface. The crucial step to control biofilm formation is by developing antiadhesion surfaces that can restrict the contact between microbes and the surfaces. Such surfaces can be developed by enhancing the wettability of a material. This can be done by combining roughness with chemical treatment onto the surface [84]. A surface is said to be superhydrophobic when it exhibits a water contact angle (WCA) above $150^{\circ}$. 


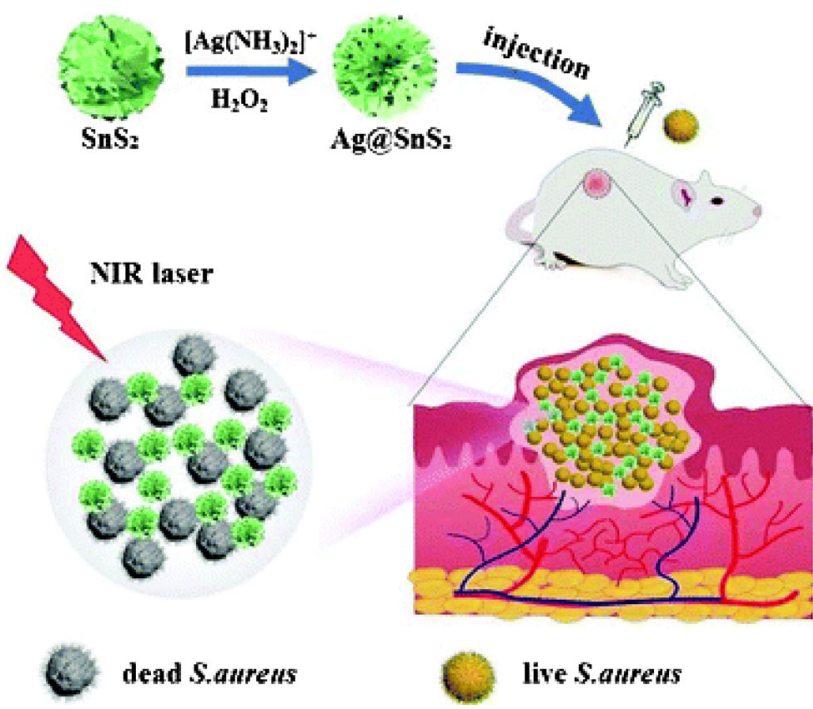

Figure 6 In vivo photothermal antibacterial activity of $\mathrm{Ag} @ \mathrm{SnS}_{2}$ material. Adapted with permission from Ref. [71] Copyright (2021) Royal Society of Chemistry.

On such surfaces, water droplet rolls off even at a small tilting angle [85], whereas, superhydrophilic surface shows a WCA equal to or less than $5^{\circ}$ and water droplet completely spread on the surface [9].

\section{Superhydrophobic surfaces}

Superhydrophobic surfaces are efficacious for a wide array of microbes inclusive of various species of bacteria, fungus, and viruses. The superhydrophobicity imparts antimicrobial character by minimizing the attachment of microbes on the surface [14].

In a study where a lotus leaf-like surface made of Ti was reported, it was observed that the bacteria were unable to adhere to the superhydrophobic surface due to the presence of trapped air nanobubbles and microbubbles in the hierarchical nanostructure. The bacteria start to assemble at the tri-phase interface, as illustrated in Fig. 7. The nanostructure and the trapped air (hydrodynamic force) minimize the area of contact among bacteria and the surfaces imparting an antifouling activity [86].

Ellinas et al. have reported antibacterial superhydrophobic micro-nanotextured surface of poly (methyl methacrylate) (PMMA) having WCA greater than $155^{\circ}$. The surface exhibited high bacterial repulsion against cyanobacteria Synechococcus sp. for a long period of $72 \mathrm{~h}$ and low bacterial adhesion upon immersion in bacterial cell solution till the fourth day. It had been previously reported that the superhydrophobicity of a surface vanishes, when kept immersed, with time due to the eventual depletion of the air layer and leads to bacterial adhesion. This paper shows that the surface design and feature sizes are important parameters to avoid this depletion of the air layer and to maintain a superhydrophobic character [73]. Privett et al. prepared an antifouling superhydrophobic surface using silica-colloid-doped fluorinated substrates. According to their findings, the presence of both roughness and chemical modification using low-energy materials are responsible for minimizing bacterial adhesion [87].

Yeongae Kim et al. have reported antifungal activity of superhydrophobic aluminum surface against Penicillium, Cladosporium, and Aspergillus which exhibited a water contact angle of $169^{\circ}$. They have observed that only superhydrophobic surface was not contaminated, while the superhydrophilic and hydrophobic surfaces were contaminated on the direct inoculation of fungal spores [88].

Like bacteria and fungus, superhydrophobic surfaces also show a reduction in viral adhesion. Katoh et al. have reported that the fabric of personal protective equipment made of non-woven polypropylene with enhanced WCA can potentially reduce the risk of virus carryover by repelling the infectious body fluids $[89,90]$. The adhesion of infected fluid on PPE can lead to a higher risk of spreading infection. Hence, superhydrophobic surfaces can lower the risk of viral infection.

The antimicrobial mechanism of superhydrophobic surfaces is mostly restricted to avoiding microbial adhesion rather than actively killing them. One of the ways to enhance the antimicrobial activity of superhydrophobic surfaces is by combining the superhydrophobicity with antimicrobial metal or metal oxide nanoparticles. This alters the roughness and also actively kills the microbes present on the surface [91, 92]. Berendjchi et al. have reported superhydrophobic and antibacterial cotton surfaces using copper doped silica nanoparticles followed by hydrophobic modification with hexadecyltrimethoxysilane. The addition of copper $(\mathrm{Cu})$ on the silica sol provides roughness to the silica surface and enhances the antibacterial property [92]. Likewise, Singh et al. have reported antimicrobial white cement composite embedded with different amounts of zinc oxide $(\mathrm{ZnO})$ nanoneedles. The surface showed biocidal action for E. coli (gram-positive bacteria), 
Table 3 Summary of studies reported on antimicrobial activity of the functionalized surfaces

\begin{tabular}{|c|c|c|c|c|}
\hline Material used & $\begin{array}{l}\text { Fabrication } \\
\text { technique }\end{array}$ & Mode of action & Microbes used & Reference \\
\hline $\begin{array}{l}\text { Poly }(N \text {-benzyl-4- } \\
\text { vinylpyridinium halide })\end{array}$ & $\begin{array}{l}\text { Radical } \\
\text { polymerization }\end{array}$ & $\begin{array}{l}\text { Chemical } \\
\text { functionalization }\end{array}$ & $\begin{array}{l}\text { E. coli (gram-negative), S. aureus (gram-positive) } \\
\text { and, influenza virus }\end{array}$ & {$[76]$} \\
\hline $\begin{array}{l}\text { N,N-dodecyl,methyl- } \\
\text { polyethylenimine }\end{array}$ & Layer by layer & $\begin{array}{l}\text { Chemical } \\
\text { functionalization }\end{array}$ & $\begin{array}{l}\text { E. coli (gram-negative) and S. aureus (gram- } \\
\text { positive) bacteria, influenza virus (H1N1) }\end{array}$ & {$[59]$} \\
\hline 3-Aminopropyltriethoxysilane & $\begin{array}{l}\text { Wet chemical } \\
\text { process }\end{array}$ & $\begin{array}{l}\text { Chemical } \\
\text { functionalization }\end{array}$ & hepatitis A virus and phages MS2 and PhiX174 & {$[64]$} \\
\hline Aminopropyltrimethoxysilane & $\begin{array}{r}\text { Chemical } \\
\text { grafting }\end{array}$ & $\begin{array}{l}\text { Chemical } \\
\text { functionalization }\end{array}$ & $\begin{array}{l}\text { E. coli (gram-negative) and S. aureus(gram- } \\
\text { positive) bacteria }\end{array}$ & {$[77]$} \\
\hline N-chloramines & $\begin{array}{r}\text { Chemical } \\
\text { grafting }\end{array}$ & $\begin{array}{l}\text { Chemical } \\
\text { functionalization }\end{array}$ & $\begin{array}{l}\text { E. coli (gram-negative) and S. aureus(gram- } \\
\text { positive) bacteria }\end{array}$ & {$[78]$} \\
\hline PEI & $\begin{array}{r}\text { Chemical } \\
\text { grafting }\end{array}$ & $\begin{array}{l}\text { Chemical } \\
\text { functionalization }\end{array}$ & $\begin{array}{l}\text { S. aureus (gram-positive bacteria) and Candida } \\
\text { spp. and } \\
\text { Cryptococcus spp. (Fungus) }\end{array}$ & {$[79]$} \\
\hline $\begin{array}{l}\text { Didodecyldimethylammonium } \\
\text { bromide (DDAB) }\end{array}$ & $\begin{array}{l}\text { Physical } \\
\text { immobilization } \\
\text { on Silica } \\
\text { nanoparticles }\end{array}$ & $\begin{array}{l}\text { Chemical } \\
\text { functionalization }\end{array}$ & $\begin{array}{l}\text { S. aureus (gram-positive bacteria), E. coli (gram- } \\
\text { negative bacteria), C. albicans (fungi), A. oryzae } \\
\text { (mold), P. ochrochloron (mold), and influenza } \\
\text { A/PR/8/34 (H1N1; virus) }\end{array}$ & {$[80]$} \\
\hline Gold NPs & Anodization & NIR irradiation & $\begin{array}{l}\text { E. coli (gram-negative), S. aureus (gram-positive } \\
\text { bacteria) }\end{array}$ & {$[60]$} \\
\hline $\mathrm{MoS}_{2}$ & $\begin{array}{l}\text { Magnetron } \\
\text { sputtering }\end{array}$ & NIR irradiation & S. aureus (gram-positive bacteria) & {$[81]$} \\
\hline $\mathrm{MnO}_{2}$ & $\begin{array}{l}\text { Hydrothermal } \\
\text { synthesis }\end{array}$ & NIR irradiation & $\begin{array}{l}\text { E. coli (gram-negative), S. aureus (gram-positive } \\
\text { bacteria) }\end{array}$ & {$[82]$} \\
\hline $\mathrm{TiO}_{2}$ & Solgel & UV light & $\begin{array}{l}\text { MS2 bacteriophage, influenza virus, and murine } \\
\text { norovirus (virus) }\end{array}$ & {$[75]$} \\
\hline $\mathrm{SiO} 2-\mathrm{TiO} 2$ & Solgel & $\begin{array}{l}\text { UV light, Visible } \\
\text { light }\end{array}$ & E. coli & {$[83]$} \\
\hline
\end{tabular}

Figure 7 Mechanism of bacterial adhesion resistance on a superhydrophobic surface. Adapted with permission from Ref. [86] Copyright (2012) Taylor \& Francis.

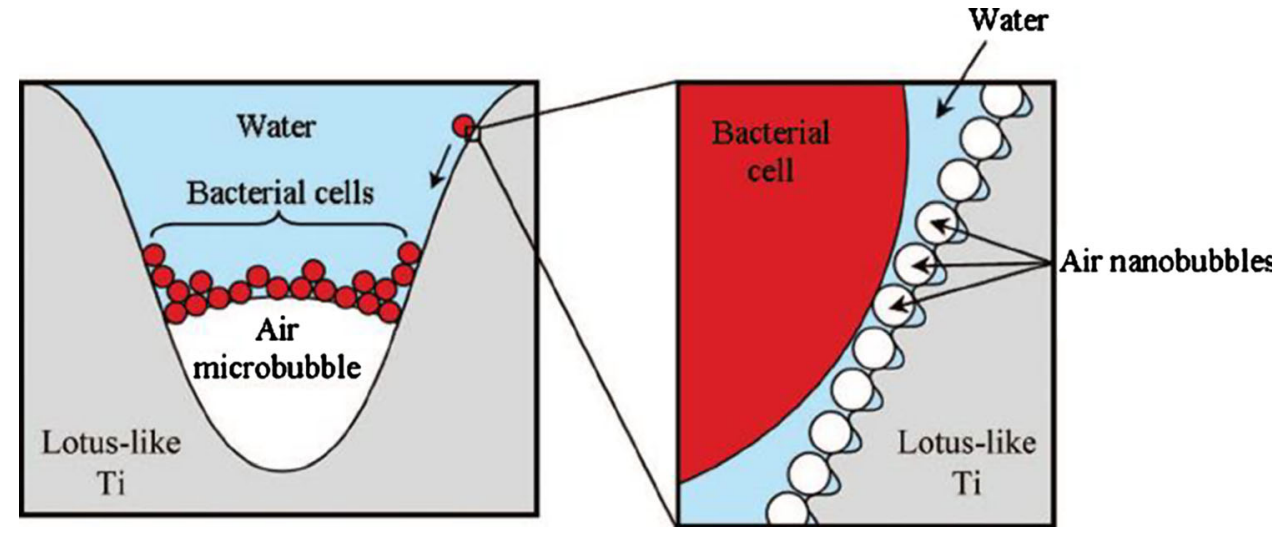

Bacillus subtilis (gram-negative bacteria), and Aspergillus niger (fungus) [74]. Dimitrakellis et al. have reported bacteria repelling and bactericidal surface against E. coli developed by superhydrophobic micro-nanotextured PMMA surface modified with $\mathrm{Cu}$ (shown in Fig. 8). The hierarchical rough surface was developed by plasma etching of PMMA, and the biocidal activity was speculated to be due to its surface structure that allowing the mechanical killing of bacteria. The presence of 

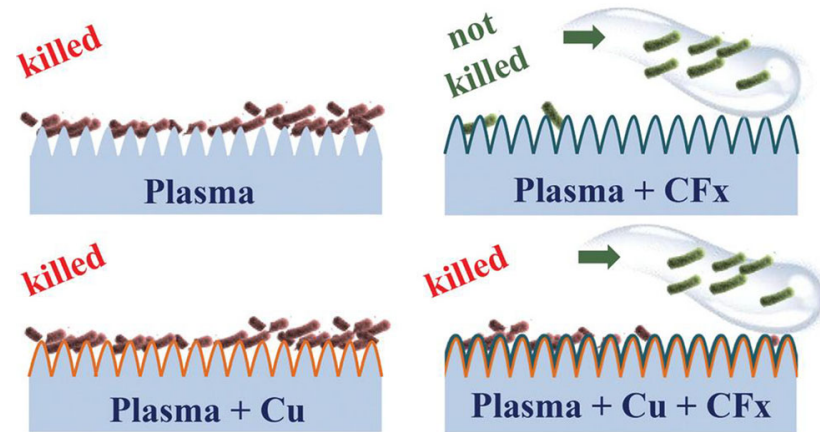

Figure 8 Schematic representation of superhydrophobic and antibacterial surface showing the bacterial repealing and simultaneous killing of bacteria. Adapted with permission from Ref. [93] Copyright (2021) Wiley-VCH.

superhydrophobic surface deposited by fluorocarbon (CFx) acted as a bacteria repealing surface by restricting the contact between bacteria and the surface. Finally, the $\mathrm{Cu}$ acted as a biocidal material and instantaneously killing any bacteria adhering to the surface [93]. Similarly, other metals and metal oxides such as silver and titanium dioxide $\left(\mathrm{TiO}_{2}\right)$ are also effective antimicrobial agents $[94,95]$. The uptake of silver and copper ions or nanoparticles by microbes leads to their death by disrupting various cellular processes such as enzyme activity, DNA replication.

\section{Superhydrophilic surfaces}

The water droplets on superhydrophilic surfaces spread promptly to completely wet the exposed area and make a compact water layer. This works as a barrier that restricts contamination on the exposed area and enables self-cleaning [85]. Based on this property, superhydrophilic surfaces exhibit antifouling activity [96].

Qian et al. developed a superhydrophilic surface with antibacterial and antifungal properties on stainless steel surfaces by depositing polydopamine (PDA) and silver nanoparticles (AgNPs). This work was inspired by mussels and was further modified with a hydrophilic material methoxy-polyethyleneglycol thiol (mPEG-SH). The water contact angle achieved was close to $0^{\circ}$, and this superhydrophillic surface showed antibacterial and antifungal activity against S. aureus, E. coli, and Penicillium F2-1. The antibacterial and antifungal activities were due to the combined effects of the antiadhesion created by water layers, the bacteria-killing ability of AgNPs, and the stereo hindrance caused by mPEG-SH molecular chains as shown in Fig. 9. Upon immersion of the surface on the inoculated medium, a huge quantity of Ag ions discharged on the medium which leads to the killing of attached and neighboring bacteria. However, the antifungal properties of superhydrophobic surfaces were tested in presence of a humid atmosphere where the bound water layer was in direct contact with the humid air. Here the released $\mathrm{Ag}$ ions were present in the bound water layer which leads to antifungal activity. This water layer remains stable due to the strong attraction of superhydrophilic surface to the water, which helps in sustaining the antifungal property of the surface. Further, the incorporation of antimicrobial metal or metal oxides enhances the antimicrobial properties of superhydrophilic surfaces by allowing higher wetting [97, 98]. Other than metal or metal oxides, hydrophilic polymers are utilized for antimicrobial surfaces [99-101]. Polyethylene glycol (PEG) is one such polymer that shows enhanced hydrophilicity with stereo hindrance effect due to long-chain PEG [101, 102].

The summary of studies reported on the antimicrobial activity of various superhydrophobic and superhydrophilic surfaces is shown in Table 4 which indicates that like superhydrophobic surfaces, these surfaces also inhibit the adhesion of microbes mainly bacteria and fungus rather than killing them directly. The affinity of water with hydrophilic surface is more in the case of high surface energy material than that of organic molecules due to which water molecules bound tightly with the superhydrophilic surface and prohibited the cell surface interaction [103].

\section{Smart surfaces}

Various types of antimicrobial surfaces have been developed in the past few decades based on the strategies discussed above. However, surfaces with single functionality have some serious drawbacks such as antifouling surfaces cannot maintain their non-adhesive property for the long term and eventually leads to biofilm formation. Also, biocidal surfaces can effectively kill the microbes, but after a certain period of time, a higher amount of debris or dead microbes starts accumulating on the surface, and as a result, it affects the functionality of the surface [108]. Therefore, combinational surfaces with kill and release ability can help in developing effective antimicrobial surfaces for the long term. The 

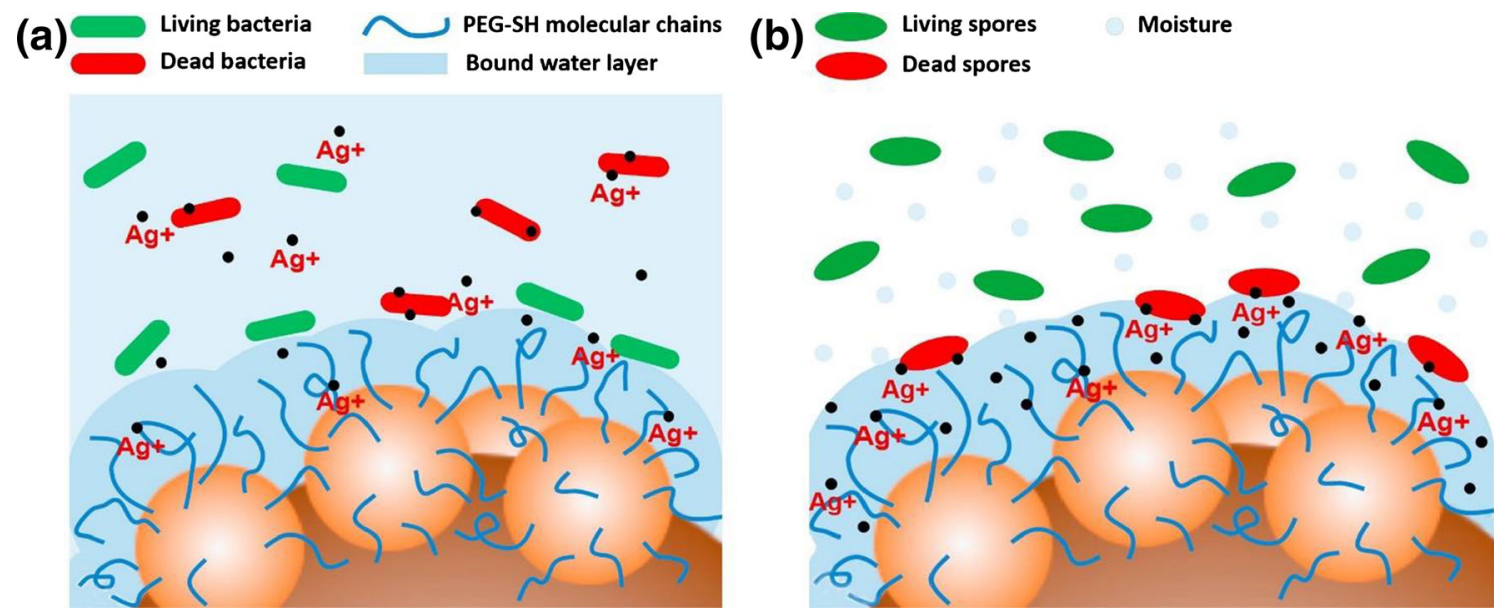

Figure 9 The schematic diagram of $\mathbf{a}$ the antibacterial and $\mathbf{b}$ antifungal mechanism of superhydrophilic surface. Adapted with permission from Ref. [98] Copyright (2019) Elsevier.

mode of action for developing smart surfaces is based on killing the microbes attached to the surface using various antimicrobial agents, and the dead microbes are released using stimuli-responsive polymers $[11,12,108]$.

One such example is of thermoresponsive polymers such as poly(N-isopropylacrylamide) (PNIPAAm) which has its lower critical solution temperature (LCST) at $32{ }^{\circ} \mathrm{C}$. Lopez et al. have reported dual functional antibacterial and antifouling surfaces against E. coli and S. epidermidis as shown in Fig. 10. In their works, lysozyme and quaternary ammonium salt (QAS) was used as a biocide and PNIPAAm was used as an antifouling material. The switchable surface was obtained by changing the temperature across the LCST of PNIPAAm. E. coli attach to the surface at $37^{\circ} \mathrm{C}$. An increase in the temperature above the $\operatorname{LCST}\left(37^{\circ} \mathrm{C}\right)$ results in the collapse of the secondary chain structure of PNIPAAm. This exposes the underlying biocide which kills the bacteria. Also, as the temperature changed below the LCST of PNIPAAm $\left(25^{\circ} \mathrm{C}\right)$, the dead bacteria are released from the surface due to the conformational change of PNIPAAm [109, 110].

Similarly, Yan et al. have reported switchable surfaces consisting of an inner antimicrobial peptide (AMP) layer surrounded by a $\mathrm{pH}$-responsive poly (methacrylic acid) (PMAA) layer as shown in Fig. 11. PMAA initially restricts bacterial adhesion due to its hierarchical surface. Once the bacteria colony formation starts, it increases the acidification of the surface which results in the collapsing of PMAA layer. This leads to the exposure of the AMP layer that kills the bacteria. In addition, the dead bacteria release from the surface as the hydrophilicity of the polymer resume due to an increase in the environment $\mathrm{pH}$ [111]. In addition, Jiang et al. have reported smart surfaces with switchable antimicrobial and antifouling properties. They have developed a surface modified with poly(N,N-dimethyl-N-(ethoxycarbonylmethyl)-N-[2'-(methacryloyloxy)ethyl]-ammonium bromide) which showed bactericidal activity against E. coli by killing more than $99.9 \%$ E. coli in one hour. However, these surfaces act as an antifouling surface upon hydrolysis to form a zwitterionic polymer and released $98 \%$ dead bacteria [112].

Developing a biocide free surface for killing bacteria is of great interest as it does not have toxicity issues or a chance of evolving multidrug resistant bacteria. Photothermal agents (PTA) are one such example of biocide free materials where biocidal activity is due to the heat generated by the PTA upon exposure to light which results in bacterial cell damage [113]. Qian et al. have developed switchable surfaces with bacteria killing and releasing ability using tannic acid $/ \mathrm{Fe}^{3+}(\mathrm{TA} / \mathrm{Fe})$ ion complex as a photothermal bactericidal agent and PNIPAAm as an antifouling material. TA/Fe showed biocidal activity against E. coli and methicillin resistant Staphylococcus aureus (MRSA) on exposure to NIR and all the dead bacteria were released from the surface at a temperature lower than the LCST of PNIPAAm [114]. Similarly, another switchable surface with photothermal bactericidal activity has been developed by Qian et al. In this work, instead of using stimuli 


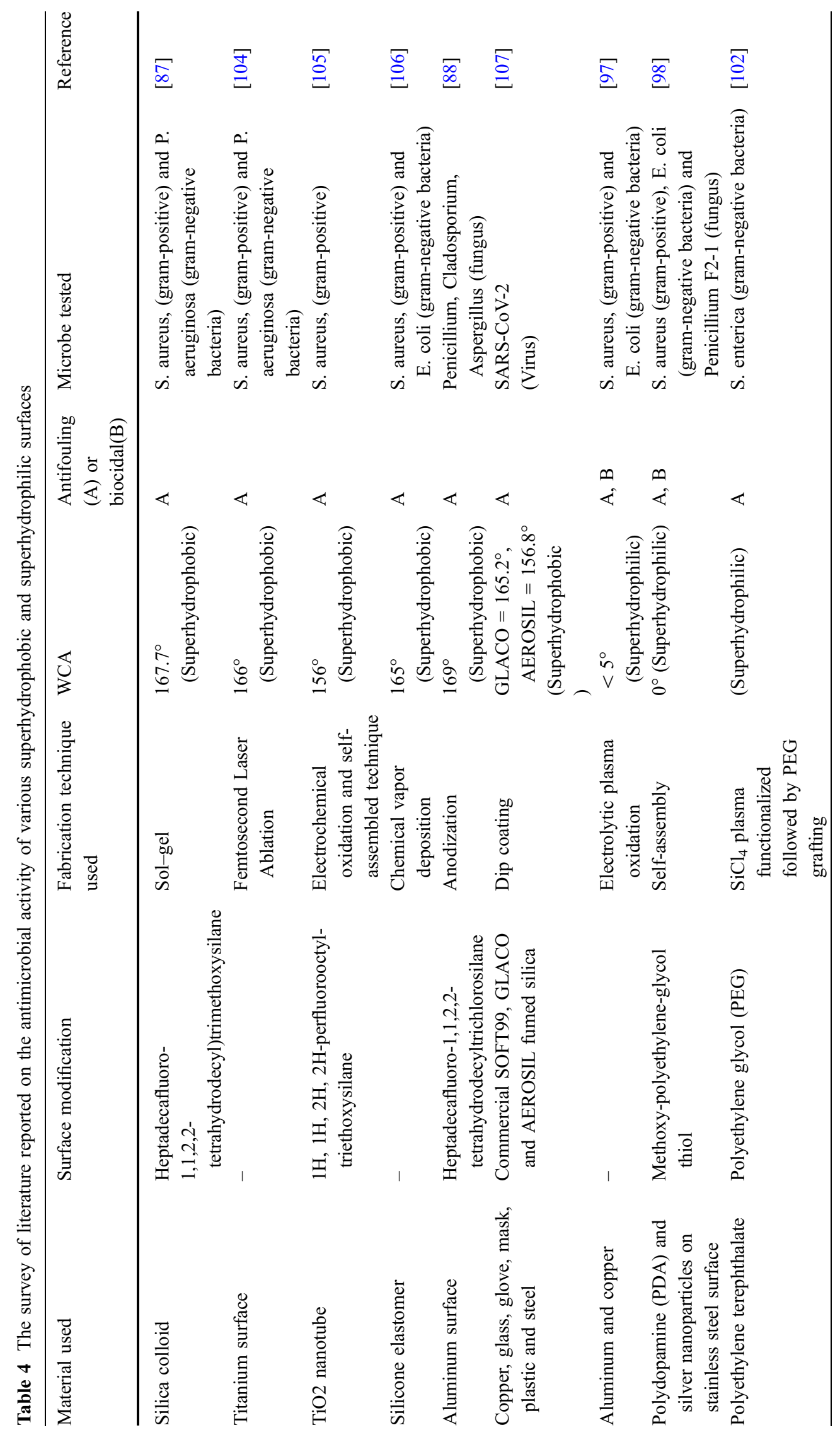



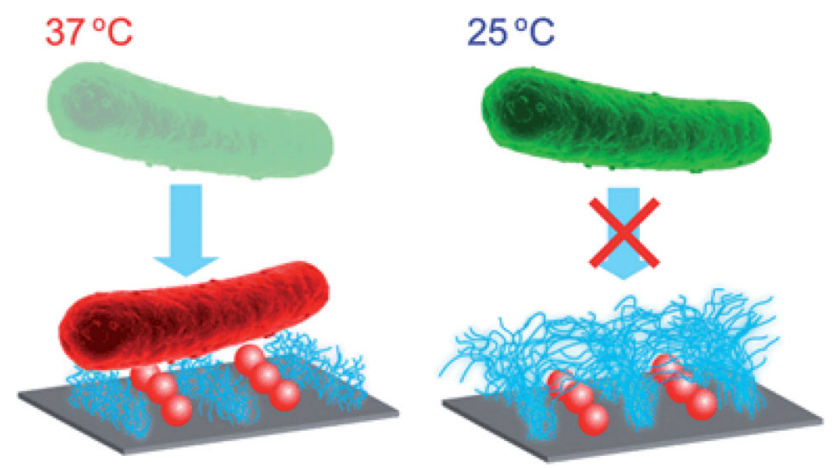

Figure 10 Thermoresponsive switchable antibacterial surface using lysozyme and PNIPAAm. Adapted with permission from Ref. [109] Copyright (2014) Royal Society of Chemistry.

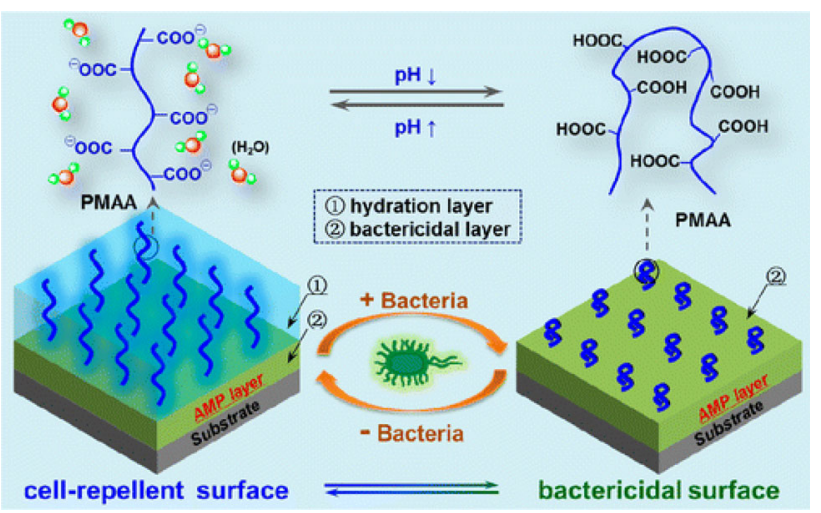

Figure 11 pH-responsive switchable antibacterial surface using AMP and PMAA. Adapted with permission from Ref. [111] Copyright (2016) American Chemical Society.

responsive polymer for switching the activities they have used gold nanoparticle layer and phase-transitioned lysozyme film (GNPL-PTNF). GNPL upon exposure to NIR showed bactericidal activity against E. coli and S. aureus with killing efficiency of $>99 \%$ and $>96 \%$ respectively, whereas PTNF on contact with vitamin $C$ solution degraded and removed all the dead bacteria present on the surface [115].

However, these types of surfaces are mostly reported for bacteria. Some of the reports on smart surfaces with dual functionality are listed in Table 5.

\section{Applications of antimicrobial surfaces}

Depending on their genotype and physiology, microorganisms can have a significant and often negative impact on materials, food sources, and the health of humans and livestock. Consequently, developing an antimicrobial surface is of significant importance in many areas. Some of the areas of applications of antimicrobial surface are as follows

\section{Health care}

Infections during surgeries can lead to devastating consequences including septic shock which leads to multiorgan failure and death. In particular, microbial contamination of implant during surgery and subsequent colonization of microbes on the implant-tissue interface may lead to post-surgery complications [7, 68]. So, developing an implant with a microstructure which either does not allow the growth of microbes or kills them directly is essential. Micro- or nanopatterned implant surfaces can be one possible way to develop antimicrobial surface which does not allow the accumulation of microbes by killing them and can reduce the risk of post-surgery complications and implant rejection [49, 128].

The viruses can spread by liquid droplets from the coughing and sneezing of an infected person. These liquid droplets can get deposited on the exposed surfaces and lead to the spreading of infection through surface contact. Rapid spread infection can lead to a pandemic similar to COVID-19. In this case, since the viruses can spread predominantly by contact with a contaminated surface, the superhydrophobic surface can play a significant role in preventing viral contamination by not allowing viral droplets to adhere to the surface. Healthcare workers have the potential risk of carrying the viruses in personal protective suits, making superhydrophobic PPE suits can reduce the risk. Also, functionalizing a surface with long alkyl chain length polycations can effectively kill the microbes, so developing a mask with an outer layer functionalized with polycations cannot allow the entry of microbes by killing them during the contact period.

\section{Food packaging}

Food spoilage leads to an excessive amount of food waste every day. One of the major reasons for spoilage is due to bacterial and fungal infections. A major amount of fruit and vegetable losses in the course of post-harvest is mainly due to diseases occurred by fungi and bacteria. Bacteria such as Geobacillus spp. and Bacillus are responsible for spoilage of canned foods and they cause ropiness in bread kept at high ambient temperatures. Also, Bacillus is responsible 
Table 5 Summary of studies reported on smart antimicrobial surfaces

\begin{tabular}{|c|c|c|c|c|}
\hline Biocidal material & Antifouling material & Microbes used & Mode of action & Reference \\
\hline Ag Nps & PNIPAAm polymer & $\begin{array}{l}\text { E. coli (gram-negative } \\
\text { bacteria) }\end{array}$ & $\begin{array}{r}\text { Temperature } \\
\text { switchable }\end{array}$ & {$[116]$} \\
\hline Lysozyme & PNIPAAm polymer & $\begin{array}{l}\text { E. coli (gram-negative), S. } \\
\text { epidermidis (gram- } \\
\text { positive) bacteria }\end{array}$ & $\begin{array}{r}\text { Temperature } \\
\text { switchable }\end{array}$ & {$[109]$} \\
\hline QAS & PNIPAAm polymer & $\begin{array}{l}\text { E. coli (gram-negative), S. } \\
\text { aureus (gram-positive) } \\
\text { bacteria }\end{array}$ & $\begin{array}{r}\text { Temperature } \\
\text { switchable }\end{array}$ & {$[117]$} \\
\hline AMP & PMAA & $\begin{array}{l}\text { S. aureus (gram-positive } \\
\text { bacteria) }\end{array}$ & $\mathrm{pH}$ switchable & {$[111]$} \\
\hline Ag NP & Zwitterions & $\begin{array}{l}\text { E. coli (gram-negative), S. } \\
\text { aureus (gram-positive) } \\
\text { bacteria }\end{array}$ & $\mathrm{pH}$ switchable & [118] \\
\hline $\begin{array}{l}\beta \text {-cyclodextrin derivative conjugated } \\
\text { with seven quaternary ammonium } \\
\text { salt groups (CDQAS) }\end{array}$ & Azobenzene & $\begin{array}{l}\text { E. coli (gram- negative } \\
\text { bacteria) }\end{array}$ & Photo switchable & [119] \\
\hline Triclosan & $\begin{array}{l}\text { Poly(3-(dimethyl (4-vinylbenzyl) } \\
\text { ammonium) propyl sulfonate) }\end{array}$ & $\begin{array}{l}\text { E. coli (gram-negative), S. } \\
\text { aureus (gram-positive) } \\
\text { bacteria }\end{array}$ & Salt responsive & {$[120]$} \\
\hline $\begin{array}{l}\text { Poly[2-(tert-butylamino) ethyl } \\
\text { methacrylate] }\end{array}$ & $\begin{array}{l}\text { Poly(3-(dimethyl (4-vinylbenzyl) } \\
\text { ammonium) propyl sulfonate) }\end{array}$ & $\begin{array}{l}\text { E. coli (gram-negative), S. } \\
\text { aureus (gram-positive) } \\
\text { bacteria }\end{array}$ & Salt responsive & {$[121]$} \\
\hline $\begin{array}{l}\beta \text {-cyclodextrin derivative conjugated } \\
\text { with seven quaternary ammonium } \\
\text { salt groups (CDQAS) }\end{array}$ & Phenylboronic acid & $\begin{array}{l}\text { E. coli (gram- negative } \\
\text { bacteria) }\end{array}$ & Sugar responsive & {$[122]$} \\
\hline $\begin{array}{l}\beta \text {-cyclodextrin derivative conjugated } \\
\text { with seven quaternary ammonium } \\
\text { salt groups (CDQAS) }\end{array}$ & $\beta$-cyclodextrin & $\begin{array}{l}\text { E. coli (gram-negative), S. } \\
\text { aureus (gram-positive) } \\
\text { bacteria }\end{array}$ & $\begin{array}{l}\text { Chemical } \\
\text { responsive }\end{array}$ & [123] \\
\hline $\begin{array}{l}\beta \text {-cyclodextrin derivative conjugated } \\
\text { with seven quaternary ammonium } \\
\text { salt groups (CDQAS) }\end{array}$ & $\begin{array}{l}\text { PNIPAAm polymer and } \\
\text { Phenylboronic acid }\end{array}$ & $\begin{array}{l}\text { E. coli (gram- negative } \\
\text { bacteria) }\end{array}$ & $\begin{array}{l}\text { Multi-responsive } \\
\text { (Temperature, } \mathrm{pH} \\
\text { and sugar) }\end{array}$ & {$[124]$} \\
\hline Ag NP & $\begin{array}{l}\text { PNIPAAm polymer and } \\
\text { Azobenzene/ cyclodextrin } \\
\text { complex }\end{array}$ & $\begin{array}{l}\text { E. coli (gram-negative), S. } \\
\text { aureus (gram-positive) } \\
\text { bacteria }\end{array}$ & $\begin{array}{l}\text { Thermoresponsive } \\
\text { and Photo } \\
\text { responsive }\end{array}$ & {$[125]$} \\
\hline $\begin{array}{l}\text { Poly(N,N-dimethylaminoethyl } \\
\text { methacrylate) }\end{array}$ & $\begin{array}{l}\text { Poly[3-(methacryloylamino) } \\
\text { propyl]dimethyl(3- } \\
\text { sulfopropyl)ammonium } \\
\text { hydroxide }\end{array}$ & $\begin{array}{l}\text { E. coli (gram-negative), S. } \\
\text { aureus (gram-positive) } \\
\text { bacteria }\end{array}$ & $\begin{array}{l}\text { Switchable surface } \\
\text { in wet condition }\end{array}$ & {$[126]$} \\
\hline Cinnamaldehyde and ampicillin & $\begin{array}{l}\text { Py- } \beta-C D \text { and lipase cleavable } \\
\text { ester linkages }\end{array}$ & $\begin{array}{l}\text { E. coli (gram-negative), } \\
\text { MRSA, S. aureus (gram- } \\
\text { positive) bacteria }\end{array}$ & $\begin{array}{l}\mathrm{pH} \text { and enzyme } \\
\text { responsive }\end{array}$ & {$[127]$} \\
\hline
\end{tabular}

for producing gas and foul smells in chilled, vacuumpacked foods and milk. Fungi such as Candida are responsible for the spoilage of fruits, vegetables, and milk products [129, 130]. Developing antimicrobial food packaging can help in increasing the shelf-life of food articles.

\section{Biofouling}

Biofouling is one of the major problems associated with the surfaces such as marine hulls [131]. These problems can be reduced by developing superhydrophilic surfaces. In the case of ship hulls, the surface is in continuous contact with water. Due to the 
strong affinity between superhydrophilic surfaces and water molecules, the water layer will act as a barrier to restrict the interaction between the fouling agent and the surface and thus prevent fouling. Also one of the reasons for pitting corrosion in metals is due to the presence of bacteria. Aluminum alloy degradation is caused by hydrocarbon-degrading bacteria Serratia marcescens and Bacillus cereus [132]. This can be prevented by developing surfaces with superhydrophobic or superhydrophilic materials which will not allow microbial adhesion or combination surface with more than one strategy to restrict the growth by killing the microbes.

\section{Common public places}

Exposed surfaces such as doorknobs, lift buttons, seating, and furniture in public places, touch surfaces in public transports have a higher risk of microbial contamination, and disinfecting the surfaces frequently is not so easy [133]. Hence, these surfaces can be coated with antimicrobial materials that can help in reducing the risk of spreading the infections.

\section{Conclusions, questions, and future prospects}

A brief summary of reports on producing antimicrobial surfaces is presented in this review. The approaches discussed involve altering the interaction between a microbe and a surface by modulating surface chemistry, wettability, and topography. The tuning of these aspects leads to 4 broad classes of antimicrobial surfaces based on a physical modification of the surface (patterned surfaces), chemical modification (functionalized surfaces), a combination of both physical and chemical modification (superwettable surfaces), and a smart surface with switchable ability to kill and release the microbes. Many of these strategies inhibit microbial adhesion while some of these kill them or both.

It has been shown that microbial adhesion decreases on increasing hydrophobicity due to the decrease in interaction and contact area, whereas, on superhydrophilic surfaces, water wets the surface completely due to the strong affinity which acts as a barrier between the microbes and the surface. These approaches based on wettability are passive and a combination with biocidal material such as metal, metal oxide, or polymers can enhance the antimicrobial properties and function as both antifouling and biocidal surfaces. Often the production of superwetting surfaces involves topographical tuning and patterning of surface and coating. However, several reports have proven the achievement of antimicrobial activity by patterned surfaces, irrespective of materials. This activity is attributed to the physical confinement of microbes and/or penetration of surface features into the microbes. Further, chemically functionalized surfaces are also capable of biocidal activity due to electrostatic interaction with the microbes leading to disruption of the cell membrane or generation of local heat by absorbing light of a respective wavelength which leads to cell death. Also, smart surfaces with both kill and release ability have been reported in the literature. This type of switchable surface shows enhanced efficiency with long-term activity.

While a vast amount of literature is available on the fabrication of antimicrobial surfaces, there are several important observations worth highlighting.

a) Most of the reports provide an account of antimicrobial activity on very few types of microbes and species. It is known that the interaction of a microbe with a surface varies significantly. For example, a surface effective against gram-negative bacteria may not be able to eliminate a gram-positive bacteria or vice versa. Even within the same type of bacteria, the surface may not be equally affected by the various species. Similarly, an enveloped virus may be easily killed as compared to a nonenveloped virus.

b) The fundamental science of the mechanism of activity remains not completely understood. This called for better multidisciplinary collaborative work. Only a comprehensive understanding can help produce broad-spectrum antimicrobial surfaces.

c) The other important consideration is on the durability of the surfaces, particularly for applications demanding long-term usage and receiving a high microbial load. Very few reports address the application-specific design of antimicrobial surfaces and present suitable results with respect to antimicrobial activity with time during service. 
d) The scalability and economic feasibility of some of these approaches also need to be thoroughly examined. While competition and scale-up favor the economy, it is crucial that the strategies are technically scalable without compromising on quality. Quality control protocols have to be designed before the product is deployed and during service.

e) Another very important consideration is the effect of these antimicrobial surfaces on commensal microbes which are part of the human microbiome. This microbiome is responsible for maintaining hygiene and providing immunity along with other specific functions such as digestion. It must be emphasized to perform tests on these organisms to ensure the normal population of these.

The development of new strategies and better materials, along with an emphasis on identifying promising technology for the market, are necessary. One of the ways to increase the antimicrobial effect is by developing a combinational surface of more than one strategy to kill a wide range of microbes. In addition, most of the strategies depend on nano-/ microstructural surface features which can get destroyed over time due to wear and environmental factor, thus reducing the efficacy of antimicrobial surfaces. Thus, new approaches toward the development of robust and long-lasting surfaces are necessary for sustainable and commercially viable technology development.

\section{Acknowledgements}

The authors acknowledge IIT Hyderabad for providing us free access to necessary journals.

\section{Declarations}

Conflict of interest The authors declare no conflict of interest.

Supplementary Information: The online version contains supplementary material available at http s://doi.org/10.1007/s10853-021-06404-0.

\section{References}

[1] Nicola M, Alsafi Z, Sohrabi C et al (2020) The socioeconomic implications of the coronavirus pandemic (COVID-19): a review. Int J Surg 78:185-193. https://doi. org/10.1016/j.ijsu.2020.04.018

[2] Smith KM, Machalaba CC, Seifman R et al (2019) Infectious disease and economics: the case for considering multisectoral impacts. One Heal 7:100080. https://doi.org/10.10 16/j.onehlt.2018.100080

[3] Rai NK, Ashok A, Akondi BR (2020) Consequences of chemical impact of disinfectants: safe preventive measures against COVID-19. Crit Rev Toxicol 50:513-520. https://d oi.org/10.1080/10408444.2020.1790499

[4] Sun Z, Ostrikov K, (Ken), (2020) Future antiviral surfaces: lessons from COVID-19 pandemic. Sustain Mater Technol 25:e00203. https://doi.org/10.1016/j.susmat.2020.e00203

[5] Chin AWH, Chu JTS, Perera MRA et al (2020) Stability of SARS-CoV-2 in different environmental conditions. The Lancet Microbe 1:e10. https://doi.org/10.1016/s2666-5247 (20)30003-3

[6] Mahmood A, Eqan M, Pervez S et al (2020) COVID-19 and frequent use of hand sanitizers; human health and environmental hazards by exposure pathways. Sci Total Environ 742:140561. https://doi.org/10.1016/j.scitotenv.20 20.140561

[7] Elbourne A, Crawford RJ, Ivanova EP (2017) Nanostructured antimicrobial surfaces: from nature to synthetic analogues. J Colloid Interface Sci 508:603-616. https://doi. org/10.1016/j.jcis.2017.07.021

[8] Elena P, Miri K (2018) Formation of contact active antimicrobial surfaces by covalent grafting of quaternary ammonium compounds. Colloids Surfaces B Biointerfaces 169:195-205. https://doi.org/10.1016/j.colsurfb.2018.04. 065

[9] Drelich J, Chibowski E, Meng DD, Terpilowski K (2011) Hydrophilic and superhydrophilic surfaces and materials. Soft Matter 7:9804-9828. https://doi.org/10.1039/c $1 \mathrm{sm} 05849 \mathrm{e}$

[10] Li Z, Guo Z (2019) Bioinspired surfaces with wettability for antifouling application. Nanoscale 11:22636-22663. h ttps://doi.org/10.1039/c9nr05870b

[11] Ding X, Duan S, Ding X et al (2018) Versatile antibacterial materials: an emerging arsenal for combatting bacterial pathogens. Adv Funct Mater 28:1-19. https://doi.org/10. 1002/adfm.201802140

[12] Zou Y, Zhang Y, Yu Q, Chen H (2021) Dual-function antibacterial surfaces to resist and kill bacteria: painting a picture with two brushes simultaneously. J Mater Sci 
Technol 70:24-38. https://doi.org/10.1016/j.jmst.2020.07. 028

[13] Wei T, Yu Q, Chen H (2019) Responsive and synergistic antibacterial coatings: fighting against bacteria in a smart and effective way. Adv Healthc Mater 8:1-24. https://doi. org/10.1002/adhm.201801381

[14] Zhang X, Wang L, Levänen E (2013) Superhydrophobic surfaces for the reduction of bacterial adhesion. RSC Adv 3:12003-12020. https://doi.org/10.1039/c3ra40497h

[15] Zhang G, Meredith TC, Kahne D (2013) On the essentiality of lipopolysaccharide to Gram-negative bacteria. Curr Opin Microbiol 16:779-785. https://doi.org/10.1016/j.mib.2013. 09.007

[16] Koebnik R, Locher KP, Van Gelder P (2000) Structure and function of bacterial outer membrane proteins: Barrels in a nutshell. Mol Microbiol 37:239-253. https://doi.org/10.10 46/j.1365-2958.2000.01983.x

[17] Tuson HH, Weibel DB (2013) Bacteria-surface interactions. Soft Matter 9:4368-4380. https://doi.org/10.1039/c $3 \mathrm{sm} 27705 \mathrm{~d}$

[18] Köhler JR, Casadevall A, Perfect J (2015) The spectrum of fungi that infects humans. Cold Spring Harb Perspect Med 5:1-22. https://doi.org/10.1101/cshperspect.a019273

[19] Talbot NJ (1997) Fungal biology: growing into the air. Curr Biol 7:78-81. https://doi.org/10.1016/s0960-9822(06)0004 $1-8$

[20] Blankenship JR, Mitchell AP (2006) How to build a biofilm: a fungal perspective. Curr Opin Microbiol 9:588-594. https://doi.org/10.1016/j.mib.2006.10.003

[21] Lagree K, Mitchell AP (2017) Fungal biofilms: inside out. Fungal Kingdom 5:873-886. https://doi.org/10.1128/9781 555819583.ch42

[22] Frank Fenner, Peter A.Bachmann, E. Paul J.Gibbs, Frederick A.Murphy, Michael J.Studdert DOW (1987) Structure and Composition of Viruses. In: Veterinary Virology. pp 3-19

[23] Villanueva RA, Rouillé Y, Dubuisson J (2005) Interactions between virus proteins and host cell membranes during the viral life cycle. Int Rev Cytol 245:171-244. https://doi.org/ 10.1016/S0074-7696(05)45006-8

[24] Thoulouze MI, Alcover A (2011) Can viruses form biofilms? Trends Microbiol 19:257-262. https://doi.org/10.10 16/j.tim.2011.03.002

[25] Mbithi JN, Springthorpe VS, Boulet JR, Sattar SA (1992) Survival of hepatitis a virus on human hands and its transfer on contact with animate and inanimate surfaces. J Clin Microbiol 30:757-763. https://doi.org/10.1128/jcm.30.4.75 7-763.1992

[26] Tiwari A, Patnayak DP, Chander Y et al (2006) Survival of two avian respiratory viruses on porous and nonporous surfaces. Avian Dis 50:284-287. https://doi.org/10.1637/7 453-101205R.1

[27] Winther B, McCue K, Ashe K, Rubino JR, JOH (2007) Environmental contamination with rhinovirus and transfer to fingers of healthy individuals by daily life activity. J Med Virol 79:1606-1610. https://doi.org/10.1002/jmv

[28] AssadianO AK (2014) Survival of microorganisms on inanimate surfaces. Use Biocidal Surfaces Reduct Healthc Acquir Infect. https://doi.org/10.1007/978-3-319-08057-4

[29] Donlan RM (2002) Biofilms: microbial life on surfaces rodney. Emerg Infect Dis 8:881-890

[30] Bazaka K, Jacob MV, Crawford RJ, Ivanova EP (2012) Efficient surface modification of biomaterial to prevent biofilm formation and the attachment of microorganisms. Appl Microbiol Biotechnol 95:299-311. https://doi.org/10. 1007/s00253-012-4144-7

[31] Costa-orlandi CB, Sardi JCO, Pitangui NS et al (2017) Fungal biofilms and polymicrobial diseases. J Fungi 3:1-24. https://doi.org/10.3390/jof3020022

[32] Maali Y, Mahieux R, Dutartre H (2020) Microbial biofilms: HTLV-1 first in line for viral biofilm but far behind bacterial biofilms. Front Microbiol. https://doi.org/10.3389/fmicb.2 020.02041

[33] Kochkodan V, Tsarenko S, Potapchenko N et al (2008) Adhesion of microorganisms to polymer membranes: a photobactericidal effect of surface treatment with $\mathrm{TiO} 2$. Desalination 220:380-385. https://doi.org/10.1016/j.desal. 2007.01.042

[34] Giaouris E, Chapot-Chartier MP, Briandet R (2009) Surface physicochemical analysis of natural Lactococcus lactis strains reveals the existence of hydrophobic and low charged strains with altered adhesive properties. Int J Food Microbiol 131:2-9. https://doi.org/10.1016/j.ijfoodmicro.2 008.09 .006

[35] Silhavy TJ, Kahne D, Walker S (2010) The bacterial cell envelope. Cold Spring Harb Perspect Biol 2:1-16

[36] Arkhipenko MV, Nikitin NA, Baranov OA et al (2019) Surface charge mapping on virions and virus-like particles of helical plant viruses. Acta Naturae 11:73-78. https://doi. org/10.32607/20758251-2019-11-4-73-78

[37] Hernando-Pérez M, Cartagena-Rivera AX, Lošdorfer Božič A et al (2015) Quantitative nanoscale electrostatics of viruses. Nanoscale 7:17289-17298. https://doi.org/10.103 9/c5nr04274g

[38] Lipke PN, Ovalle R (1998) Cell wall architecture in yeast: new structure and new challenges. J Bacteriol 180:3735-3740. https://doi.org/10.1128/jb.180.15.3735-37 40.1998 
[39] An YH, Friedman RJ (1998) Concise review of mechanisms of bacterial adhesion. $\mathrm{J}$ Biomed Mater Res $43: 338-348$

[40] Krasowska A, Sigler K (2014) How microorganisms use hydrophobicity and what does this mean for human needs? Front Cell Infect Microbiol 4:1-7. https://doi.org/10.3389/ fcimb.2014.00112

[41] Jaggessar A, Shahali H, Mathew A, Yarlagadda PKDV (2017) Bio-mimicking nano and micro-structured surface fabrication for antibacterial properties in medical implants. J Nanobiotechnology 15:1-20. https://doi.org/10.1186/s12 951-017-0306-1

[42] Kelleher SM, Habimana O, Lawler J et al (2016) Cicada wing surface topography: an investigation into the bactericidal properties of nanostructural features. ACS Appl Mater Interfaces 8:14966-14974. https://doi.org/10.1021/ac sami.5b08309

[43] Bandara CD, Singh S, Afara IO et al (2017) Bactericidal effects of natural nanotopography of dragonfly wing on escherichia coli. ACS Appl Mater Interfaces 9:6746-6760. https://doi.org/10.1021/acsami.6b13666

[44] Mainwaring DE, Nguyen SH, Webb H et al (2016) The nature of inherent bactericidal activity: insights from the nanotopology of three species of dragonfly. Nanoscale 8:6527-6534. https://doi.org/10.1039/c5nr08542j

[45] Watson GS, Green DW, Schwarzkopf L et al (2015) A gecko skin micro/nano structure - A low adhesion, superhydrophobic, anti-wetting, self-cleaning, biocompatible, antibacterial surface. Acta Biomater 21:109-122. https://d oi.org/10.1016/j.actbio.2015.03.007

[46] Hasan J, Webb HK, Truong VK et al (2013) Selective bactericidal activity of nanopatterned superhydrophobic cicada Psaltoda claripennis wing surfaces. Appl Microbiol Biotechnol 97:9257-9262. https://doi.org/10.1007/s00253012-4628-5

[47] Yang M, Ding Y, Ge X, Leng Y (2015) Control of bacterial adhesion and growth on honeycomb-like patterned surfaces. Coll Surfaces B Biointerfaces 135:549-555. https://d oi.org/10.1016/j.colsurfb.2015.08.010

[48] Ge X, Leng Y, Lu X et al (2015) Bacterial responses to periodic micropillar array. J Biomed Mater Res - Part A 103:384-396. https://doi.org/10.1002/jbm.a.35182

[49] Ge X, Ren C, Ding Y et al (2019) Micro/nano-structured $\mathrm{TiO} 2$ surface with dual-functional antibacterial effects for biomedical applications. Bioact Mater 4:346-357. https://d oi.org/10.1016/j.bioactmat.2019.10.006

[50] Ivanova EP, Hasan J, Webb HK, et al (2013) Bactericidal activity of black silicon. Nat Commun 4:1-7. https://doi. org/10.1038/ncomms3838
[51] Rosenzweig R, Marshall M, Parivar A et al (2019) Biomimetic nanopillared surfaces inhibit drug resistant filamentous fungal growth. ACS Appl Bio Mater 2:3159-3163. https://doi.org/10.1021/acsabm.9b00290

[52] Dickson MN, Liang EI, Rodriguez LA et al (2015) Nanopatterned polymer surfaces with bactericidal properties. Biointerphases 10:021010. https://doi.org/10.1116/1. 4922157

[53] Hasan J, Xu Y, Yarlagadda T et al (2020) Antiviral and antibacterial nanostructured surfaces with excellent mechanical properties for hospital applications. ACS Biomater Sci Eng 6:3608-3618. https://doi.org/10.1021/acsb iomaterials.0c00348

[54] Hasan J, Pyke A, Nair N et al (2020) Antiviral nanostructured surfaces reduce the viability of SARS-CoV-2. ACS Biomater Sci Eng 6:4858-4861. https://doi.org/10.1021/ac sbiomaterials.0c01091

[55] Chien HW, Chen XY, Tsai WP, Lee M (2020) Inhibition of biofilm formation by rough shark skin-patterned surfaces. Coll Surfaces B Biointerfaces 186:110738. https://doi.org/ 10.1016/j.colsurfb.2019.110738

[56] Ivanova EP, Hasan J, Webb HK et al (2013) Bactericidal activity of black silicon. Nat Commun 4:1-7. https://doi. org $/ 10.1038 /$ ncomms 3838

[57] Cui Q, Liu T, Li X et al (2020) Nanopillared polycarbonate surfaces having variable feature parameters as bactericidal coatings. ACS Appl Nano Mater 3:4599-4609. https://doi. org/10.1021/acsanm.0c00645

[58] Nowlin K, Boseman A, Covell A, LaJeunesse D (2014) Adhesion-dependent rupturing of Saccharomyces cerevisiae on biological antimicrobial nanostructured surfaces. J R Soc Interface. https://doi.org/10.1098/rsif.2014.0999

[59] Wong SY, Li Q, Veselinovic J et al (2010) Bactericidal and virucidal ultrathin films assembled layer by layer from polycationic $\mathrm{N}$-alkylated polyethylenimines and polyanions. Biomaterials 31:4079-4087. https://doi.org/10.1016/ j.biomaterials.2010.01.119

[60] Jin C, Su K, Tan L et al (2019) Near-infrared light photocatalysis and photothermy of carbon quantum dots and au nanoparticles loaded titania nanotube array. Mater Des 177:107845. https://doi.org/10.1016/j.matdes.2019.107845

[61] Xu Q, Yang C, Hedrick JL, Yang YY (2016) Antimicrobial silica particles synthesized via ring-opening grafting of cationic amphiphilic cyclic carbonates: effects of hydrophobicity and structure. Polym Chem 7:2192-2201. h ttps://doi.org/10.1039/c6py00194g

[62] Lin J, Qiu S, Lewis K, Klibanov AM (2003) Mechanism of bactericidal and fungicidal activities of textiles covalently modified with alkylated polyethylenimine. Biotechnol Bioeng 83:168-172. https://doi.org/10.1002/bit.10651 
[63] De Souza E, Silva JM, Hanchuk TDM, Santos MI et al (2016) Viral inhibition mechanism mediated by surfacemodified silica nanoparticles. ACS Appl Mater Interfaces 8:16564-16572. https://doi.org/10.1021/acsami.6b03342

[64] Meder F, Wehling J, Fink A et al (2013) The role of surface functionalization of colloidal alumina particles on their controlled interactions with viruses. Biomaterials 34:4203-4213. https://doi.org/10.1016/j.biomaterials.2013. 02.059

[65] Donskyi IS, Azab W, Cuellar-Camacho JL et al (2019) Functionalized nanographene sheets with high antiviral activity through synergistic electrostatic and hydrophobic interactions. Nanoscale 11:15804-15809. https://doi.org/1 0.1039/c9nr05273a

[66] Tuladhar E, de Koning MC, Fundeanu I, et al. (2012) Different virucidal activities of hyperbranched quaternary ammonium coatings on poliovirus and influenza virus. Appl Environ Microbiol. 78:2456-2458. doi: https://doi. org/10.1128/AEM.07738-11

[67] Buffet-Bataillon S, Tattevin P, Bonnaure-Mallet M, JolivetGougeon A (2012) Emergence of resistance to antibacterial agents: the role of quaternary ammonium compounds - A critical review. Int J Antimicrob Agents 39:381-389. http s://doi.org/10.1016/j.ijantimicag.2012.01.011

[68] Hasan J, Crawford RJ, Ivanova EP (2013) Antibacterial surfaces: the quest for a new generation of biomaterials. Trends Biotechnol 31:295-304. https://doi.org/10.1016/j.ti btech.2013.01.017

[69] Qi Z, Bharate P, Lai CH et al (2015) Multivalency at Interfaces: supramolecular carbohydrate-functionalized graphene derivatives for bacterial capture, release, and disinfection. Nano Lett 15:6051-6057. https://doi.org/10. 1021/acs.nanolett.5b02256

[70] Zou Y, Zhang Y, Yu Q, Chen H (2021) Photothermal bactericidal surfaces: Killing bacteria using light instead of biocides. Biomater Sci 9:10-22. https://doi.org/10.1039/d 0bm00617c

[71] Yang J, Sun L, Hui S et al (2021) Ag functionalized SnS 2 with enhanced photothermal activity for safe and efficient wound disinfection. Biomater Sci 9:1-9. https://doi.org/10. 1039/d1bm00429h

[72] Lei W, Ren K, Chen $T$ et al (2016) Polydopamine nanocoating for effective photothermal killing of bacteria and fungus upon near-infrared irradiation. Adv Mater Interfaces 3:1-6. https://doi.org/10.1002/admi.201600767

[73] Ellinas K, Kefallinou D, Stamatakis K et al (2017) Is there a threshold in the antibacterial action of superhydrophobic surfaces ? ACS Appl Mater Interfaces 9:39781-39789. h ttps://doi.org/10.1021/acsami.7b11402
[74] Singh VP, Sandeep K, Kushwaha HS et al (2018) Photocatalytic, hydrophobic and antimicrobial characteristics of $\mathrm{ZnO}$ nano needle embedded cement composites. Constr Build Mater 158:285-294. https://doi.org/10.1016/j.conbui ldmat.2017.10.035

[75] Kim MG, Kang JM, Lee JE et al (2021) Effects of calcination temperature on the phase composition, photocatalytic degradation, and virucidal activities of $\mathrm{TiO} 2$ nanoparticles. ACS Omega 6:10668-10678. https://doi.org/ 10.1021/acsomega.1c00043

[76] Xue Y, Xiao H (2015) Antibacterial/antiviral property and mechanism of dual-functional quaternized pyridinium-type copolymer. Polymers (Basel) 7:2290-2303. https://doi.org/ 10.3390/polym7111514

[77] Fernandes SCM, Sadocco P, Alonso-Varona A et al (2013) Bioinspired antimicrobial and biocompatible bacterial cellulose membranes obtained by surface functionalization with aminoalkyl groups. ACS Appl Mater Interfaces 5:3290-3297. https://doi.org/10.1021/am400338n

[78] Hou S, Xing J, Dong X et al (2017) Integrated antimicrobial and antifouling ultrafiltration membrane by surface grafting PEO and N-chloramine functional groups. J Colloid Interface Sci 500:333-340. https://doi.org/10.1016/j.jc is. 2017.04 .028

[79] Hoque J, Akkapeddi P, Yadav V et al (2015) Broad spectrum antibacterial and antifungal polymeric paint materials: Synthesis, structure-activity relationship, and membraneactive mode of action. ACS Appl Mater Interfaces 7:1804-1815. https://doi.org/10.1021/am507482y

[80] Botequim D, Maia J, Lino MMF et al (2012) Nanoparticles and surfaces presenting antifungal, antibacterial and antiviral properties. Langmuir 28:7646-7656. https://doi.o $\mathrm{rg} / 10.1021 / 1 \mathrm{a} 300948 \mathrm{n}$

[81] Li M, Li L, Su K et al (2019) Highly effective and noninvasive near-infrared eradication of a staphylococcus aureus biofilm on implants by a photoresponsive coating within 20 min. Adv Sci 6:1-16. https://doi.org/10.1002/ad vs.201900599

[82] Wang X, Su K, Tan L et al (2019) Rapid and highly effective noninvasive disinfection by hybrid Ag/CS@MnO 2 nanosheets using near-infrared light. ACS Appl Mater Interfaces 11:15014-15027. https://doi.org/10.1021/acsami. $8 b 22136$

[83] Chen Y, Tang X, Gao X et al (2019) Antimicrobial property and photocatalytic antibacterial mechanism of the TiO2doped $\mathrm{SiO} 2$ hybrid materials under ultraviolet-light irradiation and visible-light irradiation. Ceram Int 45:15505-15513. https://doi.org/10.1016/j.ceramint.2019.0 5.054 
[84] Mahanta U, Khandelwal M, Deshpande AS (2019) Wetting transition from lotus leaf to rose petal using modified fly ash. ChemistrySelect 4:7936-7942. https://doi.org/10.1002/ slct.201901535

[85] Nishimoto S, Bhushan B (2013) Bioinspired self-cleaning surfaces with superhydrophobicity, superoleophobicity, and superhydrophilicity. RSC Adv 3:671-690. https://doi.org/ 10.1039/C2RA21260A

[86] Hizal F, Rungraeng N, Lee J et al (2017) Nanoengineered superhydrophobic surfaces of aluminum with extremely low bacterial adhesivity. ACS Appl Mater Interfaces 9:12118-12129. https://doi.org/10.1021/acsami.7b01322

[87] Privett BJ, Youn J, Hong SA et al (2011) Antibacterial fluorinated silica colloid superhydrophobic surfaces. Langmuir 27:9597-9601. https://doi.org/10.1021/la 201801e

[88] Kim Y, Hwang W (2015) Wettability modified aluminum surface for a potential antifungal surface. Mater Lett 161:234-239. https://doi.org/10.1016/j.matlet.2015.08.103

[89] Meguid SA, Elzaabalawy A (2020) Potential of combating transmission of COVID-19 using novel self-cleaning superhydrophobic surfaces: part I-protection strategies against fomites. Int J Mech Mater Des 16:423-431. http s://doi.org/10.1007/s10999-020-09513-X

[90] Katoh I, Tanabe F, Kasai H et al (2019) Potential risk of virus carryover by fabrics of personal protective gowns. Front Public Heal 7:3-8. https://doi.org/10.3389/fpubh.20 19.00121

[91] Liu T, Yin B, He T et al (2012) Complementary effects of nanosilver and superhydrophobic coatings on the prevention of marine bacterial adhesion. ACS Appl Mater Interfaces 4:4683-4690. https://doi.org/10.1021/am301049v

[92] Berendjchi A, Khajavi R, Yazdanshenas ME (2011) Fabrication of superhydrophobic and antibacterial surface on cotton fabric by doped silica-based sols with nanoparticles of copper. Nanoscale Res Lett 6:1-8. https://doi.org/ 10.1186/1556-276X-6-594

[93] Dimitrakellis P, Ellinas K, Kaprou GD et al (2021) Bactericidal action of smooth and plasma micro-nanotextured polymeric surfaces with varying wettability, enhanced by incorporation of a biocidal agent. Macromol Mater Eng 306:1-10. https://doi.org/10.1002/mame.202000694

[94] Shateri Khalil-Abad M, Yazdanshenas ME (2010) Superhydrophobic antibacterial cotton textiles. J Colloid Interface Sci 351:293-298. https://doi.org/10.1016/j.jcis.2010. 07.049

[95] Ellinas K, Kefallinou D, Stamatakis K et al (2017) Is there a threshold in the antibacterial action of superhydrophobic surfaces? ACS Appl Mater Interfaces 9:39781-39789. h ttps://doi.org/10.1021/acsami.7b11402
[96] Madaeni SS, Ghaemi N, Alizadeh A, Joshaghani M (2011) Influence of photo-induced superhydrophilicity of titanium dioxide nanoparticles on the anti-fouling performance of ultrafiltration membranes. Appl Surf Sci 257:6175-6180. h ttps://doi.org/10.1016/j.apsusc.2011.02.026

[97] Nie Y, Kalapos C, Nie X et al (2010) Superhydrophilicity and antibacterial property of a Cu-dotted oxide coating surface. Ann Clin Microbiol Antimicrob 9:25. https://doi. org/10.1186/1476-0711-9-25

[98] Qian H, Yang J, Lou Y et al (2019) Mussel-inspired superhydrophilic surface with enhanced antimicrobial properties under immersed and atmospheric conditions. Appl Surf Sci 465:267-278. https://doi.org/10.1016/j.apsu sc.2018.09.173

[99] Yang WJ, Cai T, Neoh K et al (2011) Biomimetic anchors for antifouling and antibacterial polymer brushes on stainless steel. Langmuir 27:7065-7076

[100] Krishnamoorthy M, Hakobyan S, Ramstedt M, Gautrot JE (2014) Surface-initiated polymer brushes in the biomedical field: applications in membrane science. Biosensing, Cell Culture, Regenerative Medicine and Antibacterial Coatings. https://doi.org/10.1021/cr500252u

[101] Tripathi BP, Dubey NC, Stamm M (2014) Polyethylene glycol cross-linked sulfonated polyethersulfone based fi ltration membranes with improved antifouling tendency. J Memb Sci 453:263-274. https://doi.org/10.1016/j.memsc i.2013.11.007

[102] Dong B, Manolache S, Wong ACL (2011) Antifouling ability of polyethylene glycol of different molecular weights grafted onto polyester surfaces by cold plasma. Polym Bull. 66:517-528. https://doi.org/10.1007/s00289-0 10-0358-y

[103] Lu M, Zhao J, Tu W et al (2017) Combined 'spear and shield': superhydrophilic antimicrobial and antifouling mesh membrane for efficient oil-water separation through facile and environmentally friendly strategy. J Coatings Technol Res 14:243-253. https://doi.org/10.1007/s11998016-9834-0

[104] Fadeeva E, Truong VK, Stiesch M et al (2011) Bacterial retention on superhydrophobic titanium surfaces fabricated by femtosecond laser ablation. Langmuir 27:3012-3019. h ttps://doi.org/10.1021/la104607g

[105] Lin C, Tang P, Zhang W et al (2011) Effect of superhydrophobic surface of titanium on staphylococcus aureus adhesion. J Nanomater 2011:1-8. https://doi.org/10.1155/ 2011/178921

[106] Crick CR, Ismail S, Pratten J, Parkin IP (2011) An investigation into bacterial attachment to an elastomeric superhydrophobic surface prepared via aerosol assisted 
deposition. Thin Solid Films 519:3722-3727. https://oi. org/10.1016/j.tsf.2011.01.282

[107] Zhu P, Wang Y, Chu H, Wang L (2021) Superhydrophobicity preventing surface contamination as a novel strategy against COVID-19. J Colloid Interface Sci 600:613-619. h ttps://doi.org/10.1016/j.jcis.2021.05.031

[108] Wei T, Tang Z, Yu Q, Chen H (2017) Smart antibacterial surfaces with switchable bacteria-killing and bacteria-releasing capabilities. ACS Appl Mater Interfaces 9:37511-37523. https://doi.org/10.1021/acsami.7b13565

[109] Yu Q, Ista LK, López GP (2014) Nanopatterned antimicrobial enzymatic surfaces combining biocidal and fouling release properties. Nanoscale 6:4750-4757. https://doi.org/ 10.1039/c3nr06497b

[110] Yu Q, Cho J, Shivapooja P et al (2013) Nanopatterned smart polymer surfaces for controlled attachment, killing, and release of bacteria. ACS Appl Mater Interfaces 5:9295-9304. https://doi.org/10.1021/am4022279

[111] Yan S, Shi H, Song L et al (2016) Nonleaching bacteriaresponsive antibacterial surface based on a unique hierarchical architecture. ACS Appl Mater Interfaces 8:24471-24481. https://doi.org/10.1021/acsami.6b08436

[112] Cheng G, Xue H, Zhang Z et al (2008) A switchable biocompatible polymer surface with self-sterilizing and nonfouling capabilities. Angew Chemie - Int Ed 47:8831-8834. https://doi.org/10.1002/anie.200803570

[113] Kim SH, Kang EB, Jeong CJ et al (2015) Light controllable surface coating for effective photothermal killing of bacteria. ACS Appl Mater Interfaces 7:15600-15606. https://d oi.org/10.1021/acsami.5b04321

[114] Wang Y, Wei T, Qu Y et al (2020) Smart, photothermally activated, antibacterial surfaces with thermally triggered bacteria-releasing properties. ACS Appl Mater Interfaces 12:21283-21291. https://doi.org/10.1021/acsami.9b17581

[115] Qu Y, Wei T, Zhao J et al (2018) Regenerable smart antibacterial surfaces: Full removal of killed bacteria: via a sequential degradable layer. J Mater Chem B 6:3946-3955. https://doi.org/10.1039/c8tb01122b

[116] Yang H, Li G, Stansbury JW et al (2016) Smart antibacterial surface made by photopolymerization. ACS Appl Mater Interfaces 8:28047-28054. https://doi.org/10.1021/acsami. 6b09343

[117] Wang Q, Feng Y, He M et al (2018) Thermoresponsive antibacterial surfaces switching from bacterial adhesion to bacterial repulsion. Macromol Mater Eng 303:1-10. http s://doi.org/10.1002/mame.201700590

[118] Qiao Z, Yao Y, Song S et al (2019) Silver nanoparticles with $\mathrm{pH}$ induced surface charge switchable properties for antibacterial and antibiofilm applications. J Mater Chem B 7:830-840. https://doi.org/10.1039/c8tb02917b
[119] Wei T, Zhan W, Yu Q, Chen H (2017) Smart biointerface with photoswitched functions between bactericidal activity and bacteria-releasing ability. ACS Appl Mater Interfaces 9:25767-25774. https://doi.org/10.1021/acsami.7b06483

[120] Wu J, Zhang D, Wang Y et al (2019) Electric assisted saltresponsive bacterial killing and release of polyzwitterionic brushes in low-concentration salt solution. Langmuir 35:8285-8293. https://doi.org/10.1021/acs.langmuir.9b 01151

[121] Fu Y, Wang Y, Huang L et al (2018) Salt-responsive "killing and release" antibacterial surfaces of mixed polymer brushes. Ind Eng Chem Res 57:8938-8945. https://doi. org/10.1021/acs.iecr.8b01730

[122] Zhan W, Qu Y, Wei T et al (2018) Sweet switch: sugarresponsive bioactive surfaces based on dynamic covalent bonding. ACS Appl Mater Interfaces 10:10647-10655. h ttps://doi.org/10.1021/acsami.7b18166

[123] Wei T, Zhan W, Cao L et al (2016) Multifunctional and regenerable antibacterial surfaces fabricated by a universal strategy. ACS Appl Mater Interfaces 8:30048-30057. http s://doi.org/10.1021/acsami.6b11187

[124] Zhou Y, Zheng Y, Wei T et al (2020) Multistimulus responsive biointerfaces with switchable bioadhesion and surface functions. ACS Appl Mater Interfaces 12:5447-5455. https://doi.org/10.1021/acsami.9b18505

[125] Ni Y, Zhang D, Wang Y et al (2021) Host-guest interactionmediated photo/temperature dual-controlled antibacterial surfaces. ACS Appl Mater Interfaces 13:14543-14551. h ttps://doi.org/10.1021/acsami.0c21626

[126] Yan S, Luan S, Shi H et al (2016) Hierarchical polymer brushes with dominant antibacterial mechanisms switching from bactericidal to bacteria repellent. Biomacromol 17:1696-1704. https://doi.org/10.1021/acs.biomac.6b 00115

[127] Wang T, Wang C, Zhou S et al (2017) Nanovalves-based bacteria-triggered, self-defensive antibacterial coating: using combination therapy, dual stimuli-responsiveness, and multiple release modes for treatment of implant-associated infections. Chem Mater 29:8325-8337. https://doi. org/10.1021/acs.chemmater.7b02678

[128] Luong-Van E, Rodriguez I, Low HY et al (2013) Review: micro-and nanostructured surface engineering for biomedical applications. J Mater Res 28:165-174. https://doi.org/ 10.1557/jmr.2012.398

[129] Rawat S (2015) Food spoilage: microorganisms and their prevention. Pelagia Res Libr Asian J Plant Sci Res 5:47-56

[130] Casey GD, Dobson ADW (2003) Molecular detection of Candida krusei contamination in fruit juice using the citrate synthase gene cs1 and a potential role for this gene in the adaptive response to acetic acid. J Appl Microbiol 
95:13-22. https://doi.org/10.1046/j.1365-2672.2003.01940. $\mathrm{x}$

[131] Dhanasekaran D, Thajuddin N, Rashmi M et al (2009) Screening of biofouling activity in marine bacterial isolate from ship hull. Int J Environ Sci Technol 6:197-202. h ttps://doi.org/10.1007/BF03327622

[132] Rajasekar A, Ting YP (2010) Microbial corrosion of aluminum 2024 aeronautical alloy by hydrocarbon degrading bacteria bacillus cereus ACE4 and serratia marcescens ACE2. Ind Eng Chem Res 49:6054-6061. https://doi.org/ 10.1021/ie100078u
[133] Otter JA, French GL (2009) Bacterial contamination on touch surfaces in the public transport system and in public areas of a hospital in London. Lett Appl Microbiol 49:803-805. https://doi.org/10.1111/j.1472-765X.200 9.02728.x

Publisher's Note Springer Nature remains neutral with regard to jurisdictional claims in published maps and institutional affiliations. 